\title{
Study on Structural, Electronic, Optical and Mechanical Properties of MAX Phase Compounds and Applications Review Article
}

\author{
Md. Atikur Rahman*, Md. Zahidur Rahaman \\ Department of Physics, Pabna University of Science and Technology, Pabna-6600, Bangladesh
}

Email address:

atik0707phy@gmail.com (Md. Atikur Rahman)

\section{To cite this article:}

Md. Atikur Rahman, Md. Zahidur Rahaman. Study on Structural, Electronic, Optical and Mechanical Properties of MAX Phase Compounds and Applications Review Article. American Journal of Modern Physics. Vol. 4, No. 2, 2015, pp. 75-91. doi: 10.11648/j.ajmp.20150402.15

\begin{abstract}
The term "MAX phase" refers to a very interesting and important class of layered ternary transition-metal carbides and nitrides with a novel combination of both metal and ceramic-like properties that have made these materials highly regarded candidates for numerous technological and engineering applications. A relatively new class of transition metal layered compounds $\mathrm{M}_{\mathrm{n}+1} \mathrm{AX}_{\mathrm{n}}$, (MAX phases) where $\mathrm{M}$ is an early transition metal, $\mathrm{A}$ is a group $\mathrm{A}$ element most likely $\mathrm{Al}$, and $\mathrm{X}$ is $\mathrm{C}$ or $\mathrm{N}$ with $\mathrm{n}=1,2,3 \ldots \ldots \ldots$... Due to their unique structural arrangements and directional bonding, these ternary compounds possess some very outstanding mechanical and chemical properties such as damage-resistance, oxidation resistance, excellent thermal and electric conductivity, machinability, and fully reversible dislocation-based deformation. These properties can be explored in the search for new phases and their composites to meet the performance goals of advanced materials with applications in fossil energy conversion technology. Systematic and detailed computational studies on MAX phase compounds can provide fundamental understanding of the key characteristics that lead to these desirable properties and to the discovery of other new and better alloys.In this paper, we review on structural, electronic, optical and mechanical properties of around 50 MAX phase compounds and their applications. From the comparative study on the result of these compounds we think that this paper will enable to researcher to explore and predict new MAX phases and new composite alloys with better physical properties as advanced materials for various applications at extreme conditions.
\end{abstract}

Keywords: MAX Phase Compounds, Electronic, Optical and Mechanical Properties, Applications

\section{Introduction}

Metallic materials are typically characterized by being thermally and electrically conductive, plastically deformable at room temperature, readily machinable, thermal shock resistant, damage tolerant, relatively soft, etc. On the other hand, ceramics are generally characterized by high elastic moduli, good high temperature mechanical properties, good oxidation and corrosion resistance, etc. The relatively recent discovery of a family of new materials, namely the MAX phases [1] (also termed in some publications 'metallic ceramics' [2]) has provided materials that possess a useful combination of both metallic and ceramic characteristics. Recently, the interest in nanolaminated ternary $M_{n+1} A X_{n}$ (denoted 211, 312 and 413, where $n=1,2$ and 3, respectively) carbides and nitrides, so-called MAX-phases, has grown significantly. MAX phases are a family of ternary layered compounds with the formal stoichiometry $\mathrm{M}_{\mathrm{n}+1} \mathrm{AX}_{\mathrm{n}}(\mathrm{n}=1,2$,
3. ...), where $\mathrm{M}$ is the transition $\mathrm{d}$ metal; $\mathrm{A}$ is the $\mathrm{p}$ element (e.g., $\mathrm{Si}, \mathrm{Ge}, \mathrm{Al}, \mathrm{S}, \mathrm{Sn}$, etc.); X is carbon or nitrogen. Most of the MAX phases are 211 phases, some are $312 \mathrm{~s}$, and the rest are 413s. The $\mathrm{M}$ group elements include $\mathrm{Ti}, \mathrm{V}, \mathrm{Cr}, \mathrm{Zr}, \mathrm{Nb}, \mathrm{Mo}$, $\mathrm{Hf}$, and Ta. The A elements include $\mathrm{Al}, \mathrm{Si}, \mathrm{P}, \mathrm{S}, \mathrm{Ga}, \mathrm{Ge}, \mathrm{As}$, $\mathrm{Cd}, \mathrm{In}, \mathrm{Sn}, \mathrm{Tl}$, and $\mathrm{Pb}$. The $\mathrm{X}$ elements are either $\mathrm{C}$ and/or $\mathrm{N}$. First reports on the synthesis of MAX phases were presented in the works by Novotnoi et al. [3-7] performed in the 60's of the last century. Intensive studies of the physicochemical properties of MAX phases, started in the middle of the 1990 's, led to the conclusion that they were a unique class of layered materials combining chemical, physical, electrical, and mechanical properties inherent to both metals and ceramics [8]. Thus, similarly to metals, MAX phases have good heat and electric conductivity and at the same time, like ceramics, they are refractory, oxidation and corrosion resistant and have low density. These properties can be explored in the search for new phases and their composites 
that have potential to meet the performance goals for materials to be used in the next generation of fossil energy power systems at a significantly reduced cost. MAX phases are at present of increased interest as promising materials for polyfunctional high-temperature ceramics, protective coatings, sensors, and electrical contacts for catalysis. The current stage of the experimental studies of MAX phases is marked by the development of synthesis methods for these compounds, including in film and nanocrystalline states, and also by the discovery of new phases [9-11]. For example, by the magnetron deposition method new phases of $\mathrm{Ti}_{4} \mathrm{SiC}_{3}$ and
$\mathrm{Ti}_{4} \mathrm{GeC}_{3}$ (in the film state) along with a few others [11] have fairly recently been synthesized $[12,13]$. Note that at present the family consists of 60 compounds [11] involving many d and $\mathrm{p}$ elements as components (Fig. 1). Moreover, detailed investigations of the functional properties of MAX phases (in particular, doping and non-stoichiometry effects, polymorphism, tribological, mechanical, and newly found $[14,15]$ superconducting properties, etc.) as well as further searches for the promising technological use of these materials are being conducted [11].

\begin{tabular}{|c|c|c|c|c|c|c|c|c|c|c|c|c|c|c|c|}
\hline $\mathrm{Be}$ & & & & & & & & & & & B & $\mathrm{C}$ & $\mathrm{N}$ & 0 & $\mathrm{~F}$ \\
\hline $\mathrm{Mg}$ & & & & & & & & & & & $\mathrm{Al}$ & $\mathrm{Si}$ & $\mathrm{P}$ & $\mathrm{S}$ & $\mathrm{Cl}$ \\
\hline $\mathrm{Ca}$ & $\mathrm{Sc}$ & $\mathrm{Ti}$ & V & $\mathrm{Cr}$ & $\mathrm{Mn}$ & $\mathrm{Fe}$ & $\mathrm{Co}$ & $\mathrm{Ni}$ & $\mathrm{Cu}$ & $\mathrm{Zn}$ & $\mathrm{Ca}$ & $\mathrm{Ge}$ & As & $\mathrm{Se}$ & $\mathrm{Br}$ \\
\hline $\mathrm{Sr}$ & $\mathrm{Y}$ & $\mathrm{Zr}$ & $\mathrm{Nb}$ & Mo & Tc & $\mathrm{Ru}$ & $\mathrm{Rh}$ & $\mathrm{Pd}$ & $\mathrm{Ag}$ & $\mathrm{Cd}$ & In & $\mathrm{Sn}$ & $\mathrm{Sb}$ & $\mathrm{Te}$ & I \\
\hline $\mathrm{Ba}$ & $\mathrm{Lu}$ & $\mathrm{Hf}$ & $\mathrm{Ta}$ & W & $\mathrm{Re}$ & Os & $\mathrm{Ir}$ & $\mathrm{Pt}$ & $\mathrm{Au}$ & $\mathrm{Hg}$ & $\mathrm{Tl}$ & $\mathrm{Pb}$ & $\mathrm{Bi}$ & Po & At \\
\hline
\end{tabular}

Fig. 1. Periodic table of elements forming nanolaminates of the general composition $M_{n+1} A X_{n}(n=1,2,3 \ldots)$, where $M$ is a transition $d$ metal, $A$ is a pelement (Si, Al, S, Sn, etc), and X is carbon or nitrogen.

There are more than 70 known phases of MAX MAX phase compounds are shown in Table 1. compounds and this number is rapidly growing. A list of

Table 1. A list of the MAX phases known to date, in both bulk and thin film form.

\begin{tabular}{|c|c|c|}
\hline 211 Phases & 312 Phases & 413 Phases \\
\hline $\mathrm{Ti}_{2} \mathrm{CdC}, \mathrm{Sc}_{2} \mathrm{InC}, \mathrm{Ti}_{2} \mathrm{AlC}, \mathrm{Ti}_{2} \mathrm{GaC} \mathrm{Ti}_{2} \mathrm{InC}, \mathrm{Ti}_{2} \mathrm{TlC}, \mathrm{V}_{2} \mathrm{AlC}$, & $\mathrm{Ti}_{3} \mathrm{AlC}_{2}$ & $\mathrm{Ti}_{4} \mathrm{AlN}_{3}$ \\
\hline $\mathrm{Cr}_{2} \mathrm{GaC}, \mathrm{Ti}_{2} \mathrm{AlN}, \mathrm{Ti}_{2} \mathrm{GaN}, \mathrm{Ti}_{2} \mathrm{InN}, \mathrm{V}_{2} \mathrm{GaC}, \mathrm{V}_{2} \mathrm{GaN}, \mathrm{Cr}_{2} \mathrm{GaN}$, & $\mathrm{V}_{3} \mathrm{AlC}_{2}$ & $\mathrm{~V}_{4} \mathrm{AlC}_{3}$ \\
\hline $\mathrm{Ti}_{2} \mathrm{PbC}, \mathrm{V}_{2} \mathrm{GeC}, \mathrm{Cr}_{2} \mathrm{AlC}, \mathrm{Cr}_{2} \mathrm{GeC}, \mathrm{Ti}_{2} \mathrm{GeC}, \mathrm{Ti}_{2} \mathrm{SnC}, \mathrm{V}_{2} \mathrm{PC}$ & $\mathrm{Ti}_{3} \mathrm{SiC}_{2}$ & $\mathrm{Ti}_{4} \mathrm{GaC}_{3}$, \\
\hline $\mathrm{Zr}_{2} \mathrm{TlC}, \mathrm{Nb}_{2} \mathrm{AlC}, \mathrm{Nb}_{2} \mathrm{GaC}, \mathrm{Nb}_{2} \mathrm{InC}, \mathrm{V}_{2} \mathrm{AsC}, \mathrm{Ti}_{2} \mathrm{SC}, \mathrm{Zr}_{2} \mathrm{InC}$ & $\mathrm{Ti}_{3} \mathrm{GeC}_{2}$ & $\mathrm{Ti}_{4} \mathrm{SiC}_{3}$ \\
\hline $\mathrm{Zr}_{2} \mathrm{PbC}, \mathrm{Nb}_{2} \mathrm{SnC}, \mathrm{Nb}_{2} \mathrm{PC}, \mathrm{Mo}_{2} \mathrm{GaC}, \mathrm{Zr}_{2} \mathrm{InN}, \mathrm{Zr}_{2} \mathrm{TIN}, \mathrm{Zr}_{2} \mathrm{SnC}$, & $\mathrm{Ti}_{3} \mathrm{SnC}_{2}$ & $\mathrm{Ti}_{4} \mathrm{GeC}_{3}$ \\
\hline $\mathrm{Nb}_{2} \mathrm{AsC}, \mathrm{Zr}_{2} \mathrm{SC}, \mathrm{Nb}_{2} \mathrm{SC}, \mathrm{Hf}_{2} \mathrm{InC}_{2} \mathrm{Hf}_{2} \mathrm{TlC}, \mathrm{Ta}_{2} \mathrm{AlC}, \mathrm{Ta}_{2} \mathrm{GaC}$ & $\mathrm{Ta}_{3} \mathrm{AlC}_{2}$ & $\mathrm{Nb}_{4} \mathrm{AlC}_{3}$, \\
\hline $\mathrm{Hf}_{2} \mathrm{SnC}, \mathrm{Hf}_{2} \mathrm{PbC}, \mathrm{Hf}_{2} \mathrm{SnN}, \mathrm{Hf}_{2} \mathrm{SC}$ & & $\mathrm{Ta}_{4} \mathrm{AlC}_{3}$ \\
\hline
\end{tabular}
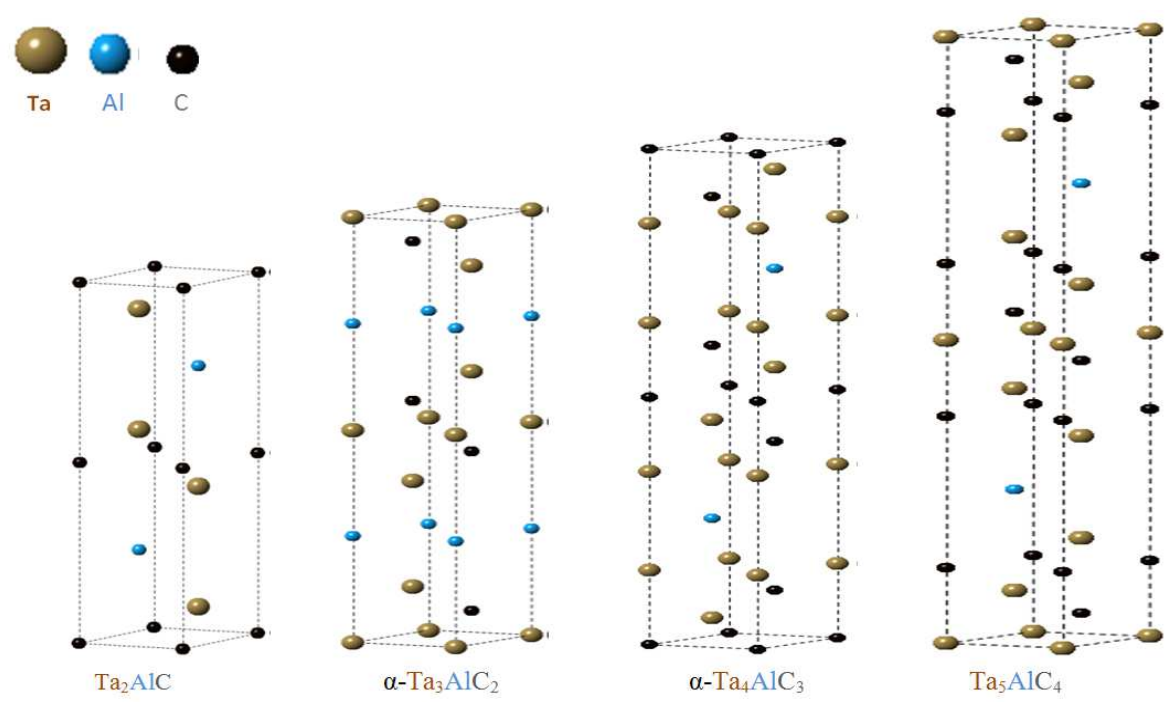

Fig. 2. Crystal structure of 211, 312, 413, 514 phases of $M=T a, A=A l$ and $X=C$. mechanical properties of MAX phase compounds which have 
been done using first-principles methods. Some of them are: $\mathrm{Ti}_{3} \mathrm{AC}_{2}(\mathrm{~A}=\mathrm{Al}, \mathrm{Si}, \mathrm{Ge}), \mathrm{Ti}_{2} \mathrm{AC}(\mathrm{A}=\mathrm{Al}, \mathrm{Ga}, \mathrm{In}, \mathrm{Si}, \mathrm{Ge}, \mathrm{Sn}, \mathrm{P}$, As, $S), \mathrm{Ti}_{2} \mathrm{AlN}, \mathrm{M}_{2} \mathrm{AlC}(\mathrm{M}=\mathrm{V}, \mathrm{Nb}, \mathrm{Cr}), \mathrm{Ta}_{\mathrm{n}+1} \mathrm{AlC}_{\mathrm{n}}(\mathrm{n}=1$ to 4), $\mathrm{Hf}_{2} \mathrm{TlC}, \mathrm{Hf}_{2} \mathrm{SnC}, \mathrm{Hf}_{2} \mathrm{PbC}, \mathrm{Hf}_{2} \mathrm{SnN}$ and $\mathrm{Hf}_{2} \mathrm{SC}$ (see Table 1).Most of them are Ti-containing phases, since they are the most common in MAX phases. They are chosen for a wide representation and for studying specific trends. The first 12 vary only by the A element and involve three ( $\left.\begin{array}{lll}3 & 1 & 2\end{array}\right)$ phases and the nine $\left(\begin{array}{lll}2 & 1 & 1\end{array}\right)$ phases. In addition to carbides, one example of nitride, $\mathrm{Ti}_{2} \mathrm{AlN}$ is also included. This is followed by three other $\left(\begin{array}{lll}2 & 1 & 1\end{array}\right)$ phases, $(\mathrm{V}, \mathrm{Nb}, \mathrm{Cr})_{2} \mathrm{AlC}$ where the transition metal $\mathrm{M}$ have different d-electron configurations. The Ta-Al-C group is chosen to study the effect of the number of MX layers (see Fig.2). The calculated results include: band structures, total and partial density of states, effective atomic charges, quantitative bond order values, interband optical conductivities, elastic coefficients, bulk modulus, shear modulus, Young's modulus, and Poisson's ratio. By systematically analyzing these results and in comparison with available experimental data, several important features on structural stability, interatomic bonding and optical conductivities are identified. These results enable us to build a data base to facilitate the search for new MAX phases and new composite alloys with the potential of having better physical properties as advanced materials.

The publication of papers on the MAX phases has shown an almost exponential increase in the past decade. The existence of further MAX phases has been reported or proposed. In addition to surveying this activity, the synthesis of MAX phases in the forms of bulk, films and powders is reviewed, together with their physical, mechanical and corrosion/oxidation properties. Recent research and development has revealed potential for the practical application of the MAX phases (particularly using the pressureless sintering and physical vapour deposition coating routes) as well as of MAX based composites. The challenges for the immediate future are to explore further and characterize the MAX phases reported to date and to make further progress in facilitating their industrial application.

\section{Early History of MAX Phase Compounds}

The MAX phases have two histories. The first spans the time they were discovered in the early and mid-1960s to roughly the mid-1990s, when, for the most part, they were ignored. The second is that of the last 15 years or so, when interest in these phases has exploded. The ternary compound, $\mathrm{Ti}_{3} \mathrm{SiC}_{2}$, was first synthesized and fully characterized by Dr. Michel Barsoum's research group at Drexel University in the 1990s. A year later they showed that this compound was but one of over sixty phases,[16] most discovered and produced in powder form in the 1960 s by H. Nowotny and coworkers [17]. In 1999 they discovered $\mathrm{Ti}_{4} \mathrm{AlN}_{3}$ and realized that they were dealing with a much larger family of solids that all behaved similarly. Since 1996, when the first paper was published on the subject, tremendous progress has been made in understanding the properties of these phases and the 1996 article [18] has been cited over 650 times [19].

\section{Crystal Structures of MAX Phase Compounds}

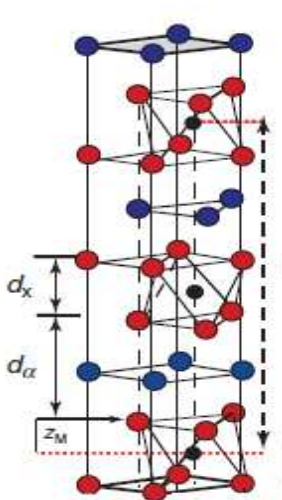

(a)

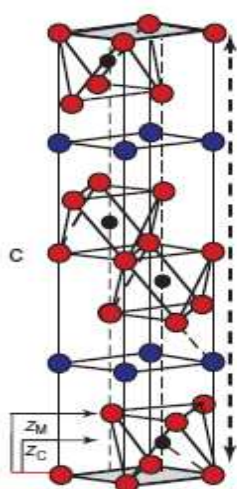

(b)

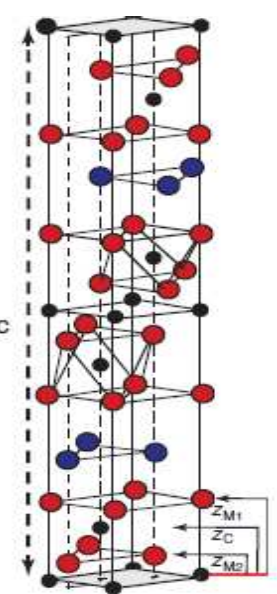

(c)
Fig. 2.1. Unit cells of (a) 211, (b) 312 and (c) 413 phases. The c parameters are depicted by vertical dashed lines. $d_{x}$ denotes the thickness-from atom center to center of the $M_{n+1} X_{n}$ layers; $d_{\alpha}$ that of A layers. It follows that that for the 211 phases $c=2 d_{\alpha}+2 d_{x}$. Also shown are the various $z$ values (see Table 2).

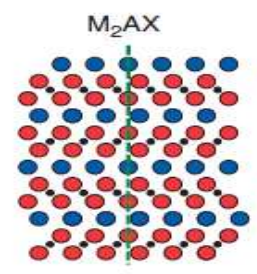

(a)

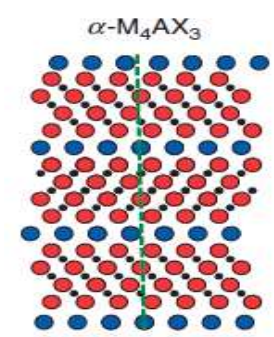

(d)

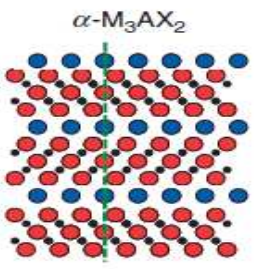

(b)

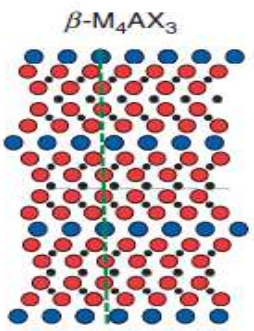

(e)

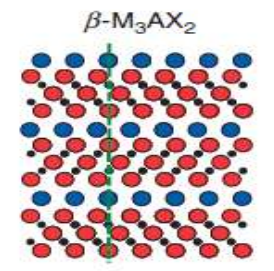

(c)

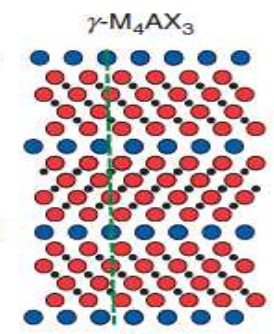

(f)
Fig. 3. Schematics of (1120) planes in (a) $M_{2} A X$, (b) $\alpha-M_{3} A X_{2}$, (c) $\beta-M_{3} A X_{2}$, (d) $\alpha-M_{4} A X_{3}$, (e) $\beta-M_{4} A X_{3}$ and (f) $\gamma-M_{4} A X_{3}$. Note that it is only in the $\alpha-$ $M_{3} A X_{2}$ structure that the $A$ atoms lie on top of each other.

MAX-phase crystals have a hexagonal symmetry in space group $P 63 / m m c$. For the 211 structure, there are three inequivalent atoms; in the 312 , there are four, and in the 413 , there are five. The coordinates and internal parameters $Z_{M}$ of all the atoms are listed in Table 2 for the various polymorphs. For the 211 phases, there is only one polymorph (Figure $3 a$ ). In the 312 case there are two, $\alpha$ and $\beta$, shown in Figures $3 b$ and $\mathrm{c}$, respectively. For the 413 phases, there are three 
polymorphs, viz. $\alpha, \beta$, and $\gamma$, shown in Figures 3d, e and f, MAX phase compounds are listed in Table 3 [22-35]. respectively. The density (D) and lattice parameters $(a, c)$ of

Table 2. Sites and idealized coordinates of the $M_{n+1} A X_{n}$ phases for $n=1-3$. Also listed are the currently known polymorphs. The fifth column lists the canonical positions.

\begin{tabular}{|c|c|c|c|c|c|c|}
\hline \multirow[t]{3}{*}{ Atoms } & \multicolumn{4}{|c|}{ Chemistry/archetypical phase } & \multirow{3}{*}{$\begin{array}{l}\mathbf{Z}_{\mathbf{M}} \text { Range } \\
- \\
-\end{array}$} & \multirow{3}{*}{$\begin{array}{l}\text { Notes and reference } \\
\text { Kudielka and Rohde (1960) } \\
\text { - }\end{array}$} \\
\hline & $\mathrm{M}_{2} \mathrm{AX} / \mathrm{T}$ & & & & & \\
\hline & Wyckoff & $\mathrm{x}$ & $\mathrm{y}$ & $Z_{\mathrm{i}}$ (canonical) & & \\
\hline A & $2 d$ & $1 / 3$ & $2 / 3$ & $3 / 4$ & - & \\
\hline M & $4 \mathrm{f}$ & $2 / 3$ & $1 / 3$ & $1 / 12(0.083)$ & $0.07-0.1$ & $\mathrm{Z}_{\mathrm{M}}$ in Figure $2.1 \mathrm{a}$ \\
\hline $\mathrm{X}$ & $2 \mathrm{a}$ & 0 & 0 & 0 & - & \\
\hline \multicolumn{6}{|c|}{$\alpha-\mathrm{M}_{3} \mathrm{AX}_{2} / \mathrm{Ti}_{3} \mathrm{SiC}_{2}$} & Jeitschko and Nowotny (1967) \\
\hline A & $2 b$ & 0 & 0 & $4 / 16$ & - & - \\
\hline $\mathrm{M}_{1}$ & $4 \mathrm{f}$ & $1 / 3$ & $2 / 3$ & $2 / 16(0.125)$ & $0.131-0.138$ & $\mathrm{Z}_{\mathrm{M} 1}$ in Figure $2.1 \mathrm{~b}$ \\
\hline $\mathrm{M}_{\mathrm{II}}$ & $2 \mathrm{a}$ & 0 & 0 & 0 & - & - \\
\hline $\mathrm{X}_{1}$ & $4 f$ & $2 / 3$ & $1 / 3$ & $1 / 16(0.0625)$ & 0.0722 & $\mathrm{Z}_{\mathrm{C}}$ in Figure $2.1 \mathrm{~b}$ \\
\hline \multicolumn{6}{|c|}{$\beta-\mathrm{M}_{3} \mathrm{AX}_{2} / \mathrm{Ti}_{3} \mathrm{SiC}_{2}$} & Farber et al. (1999) \\
\hline A & $2 d$ & $1 / 3$ & $2 / 3$ & $4 / 16$ & - & Should be quite similar in \\
\hline $\mathrm{M}_{1}$ & $4 \mathrm{f}$ & $1 / 3$ & 2.3 & $2 / 16(0.125)$ & 0.1355 & Properties to $\alpha-\mathrm{M}_{3} \mathrm{AX}_{2}$ \\
\hline $\mathrm{M}_{\text {II }}$ & $2 a$ & 0 & 0 & 0 & - & \\
\hline $\mathrm{X}_{1}$ & $4 \mathrm{f}$ & $2 / 3$ & $1 / 3$ & $1 / 16(0.0625)$ & 0.072 & \\
\hline \multicolumn{6}{|c|}{$\alpha-\mathrm{M}_{4} \mathrm{AX}_{3} / \mathrm{Ti}_{4} \mathrm{AlN}_{3}$} & Barsoum et al. (1999c) and Rawn et al. (2000) \\
\hline A & $2 \mathrm{c}$ & $1 / 3$ & $2 / 3$ & $5 / 20$ & - & - \\
\hline $\mathrm{M}_{1}$ & $4 e$ & 0 & 0 & $3 / 20(0.15)$ & $0.155-0.158$ & $\mathrm{Z}_{\mathrm{M} 1}$ in Figure $2.1 \mathrm{c}$ \\
\hline $\mathrm{M}_{\text {II }}$ & $4 \mathrm{f}$ & $1 / 3$ & $2 / 3$ & $1 / 20(0.05)$ & $0.052-0.055$ & $\mathrm{Z}_{\mathrm{M} 2}$ in Figure $2.1 \mathrm{c}$ \\
\hline $\mathrm{X}_{1}$ & $2 a$ & 0 & 0 & 0 & - & - \\
\hline $\mathrm{X}_{\mathrm{II}}$ & $4 \mathrm{f}$ & $2 / 3$ & $1 / 3$ & $2 / 20$ & 0.103-0.109 & $\mathrm{Z}_{\mathrm{C}}$ in Figure $2.1 \mathrm{c}$ \\
\hline \multicolumn{6}{|c|}{$\beta-\mathrm{M}_{4} \mathrm{AX}_{3} / \mathrm{Ta}_{4} \mathrm{AlC}_{3}$} & Eklund et al. (2007) \\
\hline A & $2 \mathrm{c}$ & $1 / 3$ & $2 / 3$ & $5 / 20$ & - & - \\
\hline $\mathrm{M}_{1}$ & $4 \mathrm{e}$ & $1 / 3$ & $2 / 3$ & $12 / 20(0.6)$ & 0.658 & - \\
\hline $\mathrm{M}_{\text {II }}$ & $4 \mathrm{f}$ & $1 / 3$ & $2 / 3$ & $1 / 20$ & 0.055 & Eklund et al. (2007) \\
\hline $\mathrm{X}_{1}$ & $2 a$ & 0 & 0 & 0 & - & - \\
\hline $\mathrm{X}_{\mathrm{II}}$ & $4 \mathrm{e}$ & $2 / 3$ & $1 / 3$ & $2 / 20$ & 0.103 & - \\
\hline \multicolumn{6}{|c|}{$\gamma-\mathrm{M}_{4} \mathrm{AX}_{3} / \mathrm{Ta}_{4} \mathrm{GaC}_{3}$} & Etzkorn et al. (2009) \\
\hline A & $2 c$ & $1 / 3$ & $2 / 3$ & $5 / 20$ & - & - \\
\hline $\mathrm{M}_{1}$ & $4 e$ & 0 & 0 & $3 / 20(0.15)$ & 0.156 & - \\
\hline $\mathrm{M}_{\text {II }}$ & $4 \mathrm{f}$ & $1 / 3$ & $2 / 3$ & $1 / 20$ & 0.056 & Etzkorn et al. (2009) and He et al. (2011) \\
\hline $\mathrm{X}_{1}$ & $2 a$ & 0 & 0 & 0 & - & - \\
\hline $\mathrm{X}_{\mathrm{II}}$ & $4 \mathrm{f}$ & $2 / 3$ & $1 / 3$ & $2 / 20$ & 0.1065 & - \\
\hline
\end{tabular}

Table 3. Density and lattice parameters of 77 Max phase compounds.

\begin{tabular}{|c|c|c|c|}
\hline No. & Compounds & Density $\mathrm{D},\left(\mathrm{Mgm}^{-3}\right)$ & Lattice parameters a, $c(\AA)$ \\
\hline \multicolumn{4}{|c|}{211 Phases } \\
\hline 1 & $\mathrm{Sc}_{2} \mathrm{AlC}$ & 2.99 & $3.280,15.373$ \\
\hline 2 & $\mathrm{Sc}_{2} \mathrm{GaC}$ & 3.93 & $3.253,15.813$ \\
\hline 3 & $\mathrm{Sc}_{2} \operatorname{InC}$ & 4.72 & $3.272,16.452$ \\
\hline 4 & $\mathrm{Sc}_{2} \mathrm{TlC}$ & 6.60 & $3.281,16.530$ \\
\hline 5 & $\mathrm{Ti}_{2} \mathrm{AlC}$ & 4.11 & $3.051,13.637$ \\
\hline 6 & $\mathrm{Ti}_{2} \mathrm{AlN}$ & 4.31 & $2.989,13.614$ \\
\hline 7 & $\mathrm{Ti}_{2} \mathrm{SiC}$ & 4.35 & $3.052,12.873$ \\
\hline 8 & $\mathrm{Ti}_{2} \mathrm{PC}$ & 4.56 & $3.191,11.457$ \\
\hline 9 & $\mathrm{Ti}_{2} \mathrm{SC}$ & 4.62 & $3.216,11.22$ \\
\hline 10 & $\mathrm{Ti}_{2} \mathrm{GaC}$ & 5.53 & $3.07,13.52$ \\
\hline 11 & $\mathrm{Ti}_{2} \mathrm{GaN}$ & 5.75 & $3.00,13.3$ \\
\hline 12 & $\mathrm{Ti}_{2} \mathrm{GeC}$ & 5.30 & $3.07,12.93$ \\
\hline 13 & $\mathrm{Ti}_{2} \mathrm{AsC}$ & 5.71 & $3.209,11.925$ \\
\hline 14 & $\mathrm{Ti}_{2} \mathrm{CdC}$ & 9.71 & $3.1,14.41$ \\
\hline 15 & $\mathrm{Ti}_{2} \mathrm{InC}$ & 6.30 & $3.134,14.077$ \\
\hline 16 & $\mathrm{Ti}_{2} \mathrm{InN}$ & 6.54 & $3.07,13.97$ \\
\hline 17 & $\mathrm{Ti}_{2} \mathrm{SnC}$ & 6.10 & $3.163,13.679$ \\
\hline 18 & $\mathrm{Ti}_{2} \mathrm{TlC}$ & 8.63 & $3.15,13.98$ \\
\hline 19 & $\mathrm{Ti}_{2} \mathrm{PbC}$ & 8.55 & $3.20,13.81$ \\
\hline
\end{tabular}


Md. Atikur Rahman and Md. Zahidur Rahaman: Study on Structural, Electronic, Optical and Mechanical Properties of MAX Phase Compounds and Applications Review Article

\begin{tabular}{|c|c|c|c|}
\hline No. & Compounds & Density $\mathrm{D},\left(\mathrm{Mgm}^{-3}\right)$ & Lattice parameters a, c( $(\AA)$ \\
\hline 20 & $\mathrm{~V}_{2} \mathrm{AlC}$ & 4.07 & $3.1,13.83$ \\
\hline 21 & $\mathrm{~V}_{2} \mathrm{SiC}$ & 5.20 & $2.955,11.983$ \\
\hline 22 & $\mathrm{~V}_{2} \mathrm{PC}$ & 5.38 & $3.077,10.91$ \\
\hline 23 & $\mathrm{~V}_{2} \mathrm{GaC}$ & 6.39 & $2.93,12.84$ \\
\hline 24 & $\mathrm{~V}_{2} \mathrm{GaN}$ & 5.94 & $3.00,13.3$ \\
\hline 25 & $\mathrm{~V}_{2} \mathrm{GeC}$ & 6.49 & $3.00,12.25$ \\
\hline 26 & $\mathrm{~V}_{2} \mathrm{AsC}$ & 6.63 & $3.11,11.3$ \\
\hline 27 & $\mathrm{Cr}_{2} \mathrm{AlC}$ & 5.21 & $2.863,12.814$ \\
\hline 28 & $\mathrm{Cr}_{2} \mathrm{GaC}$ & 6.81 & $2.88,12.61$ \\
\hline 29 & $\mathrm{Cr}_{2} \mathrm{GaN}$ & 6.82 & $2.875,12.77$ \\
\hline 30 & $\mathrm{Cr}_{2} \mathrm{GeC}$ & 6.88 & $2.95,12.08$ \\
\hline 31 & $\mathrm{Zr}_{2} \mathrm{AlC}$ & 5.78 & $3.2104,14.2460$ \\
\hline 32 & $\mathrm{Zr}_{2} \mathrm{AlN}$ & 5.83 & $3.2155,14.2134$ \\
\hline 33 & $\mathrm{Zr}_{2} \mathrm{SC}$ & 6.20 & $3.40,12.13$ \\
\hline 34 & $\mathrm{Zr}_{2} \operatorname{InC}$ & 7.1 & $3.34,14.91$ \\
\hline 35 & $\mathrm{Zr}_{2} \operatorname{InN}$ & 7.53 & $3.27,14.83$ \\
\hline 36 & $\mathrm{Zr}_{2} \mathrm{SnC}$ & 6.9 & $3.3576,14.57$ \\
\hline 37 & $\mathrm{Zr}_{2} \mathrm{TlC}$ & 9.17 & $3.36,14.78$ \\
\hline 38 & $\mathrm{Zr}_{2} \mathrm{TIN}$ & 9.60 & $3.3,14.71$ \\
\hline 39 & $\mathrm{Zr}_{2} \mathrm{PbC}$ & 8.2 & $3.38,14.66$ \\
\hline 40 & $\mathrm{Nb}_{2} \mathrm{AlC}$ & 6.50 & $3.10,13.8$ \\
\hline 41 & $\mathrm{Nb}_{2} \mathrm{PC}$ & 7.09 & $3.28,11.5$ \\
\hline 42 & $\mathrm{Nb}_{2} \mathrm{SC}_{0.4}$ & 7.01 & $3.27,11.4$ \\
\hline 43 & $\mathrm{Nb}_{2} \mathrm{SC}_{\mathrm{x}}$ & - & - \\
\hline 44 & $\mathrm{Nb}_{2} \mathrm{GaC}$ & 7.73 & $3.13,13.56$ \\
\hline 45 & $\mathrm{Nb}_{2} \operatorname{InC}$ & 8.3 & $3.17,14.37$ \\
\hline 46 & $\mathrm{Nb}_{2} \mathrm{SnC}$ & 8.3 & $3.214,13.802$ \\
\hline 47 & $\mathrm{Nb}_{2} \mathrm{AsC}$ & 8.025 & $3.31,11.9$ \\
\hline 48 & $\mathrm{Mo}_{2} \mathrm{GaC}$ & 8.79 & $3.01,13.18$ \\
\hline 49 & $\mathrm{Hf}_{2} \mathrm{AlC}$ & 10.23 & $3.2121,14.3830$ \\
\hline 50 & $\mathrm{Hf}_{2} \mathrm{AlN}$ & 10.92 & $3.1380,14.1872$ \\
\hline 51 & $\mathrm{Hf}_{2} \mathrm{SC}$ & 11.36 & $3.36,11.99$ \\
\hline 52 & $\mathrm{Hf}_{2} \operatorname{InC}$ & 11.24 & $3.309,14.723$ \\
\hline 53 & $\mathrm{Hf}_{2} \mathrm{SnC}$ & 11.2 & $3.320,14.388$ \\
\hline 54 & $\mathrm{Hf}_{2} \mathrm{SnN}$ & 7.72 & $3.31,14.3$ \\
\hline 55 & $\mathrm{Hf}_{2} \mathrm{TlC}$ & 13.65 & $3.32,14.62$ \\
\hline 56 & $\mathrm{Hf}_{2} \mathrm{PbC}$ & 11.5 & $3.55,14.46$ \\
\hline 57 & $\mathrm{Ta}_{2} \mathrm{AlC}$ & 11.46 & $3.079,13.860$ \\
\hline 58 & $\mathrm{Ta}_{2} \mathrm{GaC}$ & 13.05 & $3.10,13.57$ \\
\hline \multicolumn{4}{|c|}{312 Phases } \\
\hline 1 & $\mathrm{Ti}_{3} \mathrm{SiC}_{2}$ & 4.52 & $3.0665,17.671$ \\
\hline 2 & $\mathrm{Ti}_{3} \mathrm{AlC}_{2}$ & 4.2 & $3.065,18.487$ \\
\hline 3 & $\mathrm{Ti}_{3} \mathrm{GeC}_{2}$ & 5.22 & $3.07,17.76$ \\
\hline 4 & $\mathrm{Ti}_{3} \mathrm{SnC}_{2}$ & 5.99 & $3.1366,18.650$ \\
\hline 5 & $\mathrm{~V}_{3} \mathrm{SiC}_{2}$ & 5.27 & $2.915,17.535$ \\
\hline 6 & $\left(\mathrm{~V}_{0.5} \mathrm{Cr}_{0.05}\right)_{3} \mathrm{AlC}_{2}$ & 5.31 & $2.892,17.73$ \\
\hline 7 & $\mathrm{Nb}_{3} \mathrm{SiC}_{2}$ & 7.22 & $3.13,17.94$ \\
\hline 8 & $\mathrm{Ta}_{3} \mathrm{AlC}_{2}$ & 12.43 & $3.0930,19.159$ \\
\hline \multicolumn{4}{|c|}{413 Phases } \\
\hline 1 & $\mathrm{Ti}_{4} \mathrm{AlN}_{3}$ & 4.58 & $2.988,23.372$ \\
\hline 2 & $\mathrm{Ti}_{4} \mathrm{SiC}_{3}$ & 4.65 & $3.05,22.67$ \\
\hline 3 & $\mathrm{Ti}_{4} \mathrm{GeC}_{3}$ & - &,- 22.7 \\
\hline 4 & $\mathrm{~V}_{4} \mathrm{AlC}_{3}$ & 5.24 & $2.931,22.719$ \\
\hline 5 & $\mathrm{Nb}_{4} \mathrm{AlC}_{3}$ & 6.97 & $3.123,24.109$ \\
\hline 6 & $\alpha-\mathrm{Nb}_{4} \mathrm{SiC}_{3}$ & - & $3.1819,22.9877$ \\
\hline 7 & $\mathrm{Ta}_{4} \mathrm{AlC}_{3}$ & 13.18 & $3.092,23.708$ \\
\hline 8 & $\mathrm{Ti}_{4} \mathrm{GaC}_{3}$ & 5.17 & $3.0690,23.440$ \\
\hline \multicolumn{4}{|c|}{514 Phase } \\
\hline 1 & $\mathrm{Ti}_{5} \mathrm{SiC}_{4}$ & 4.81 & $3.04,27.24$ \\
\hline $615 \mathrm{I}$ & & & \\
\hline \multirow{2}{*}{\multicolumn{4}{|c|}{$\begin{array}{l}1 \\
716 \text { Phase }\end{array}$}} \\
\hline & & & \\
\hline 1 & $\mathrm{Ti}_{7} \mathrm{SnC}_{6}$ & 4.80 & $3.2,4.1$ \\
\hline
\end{tabular}



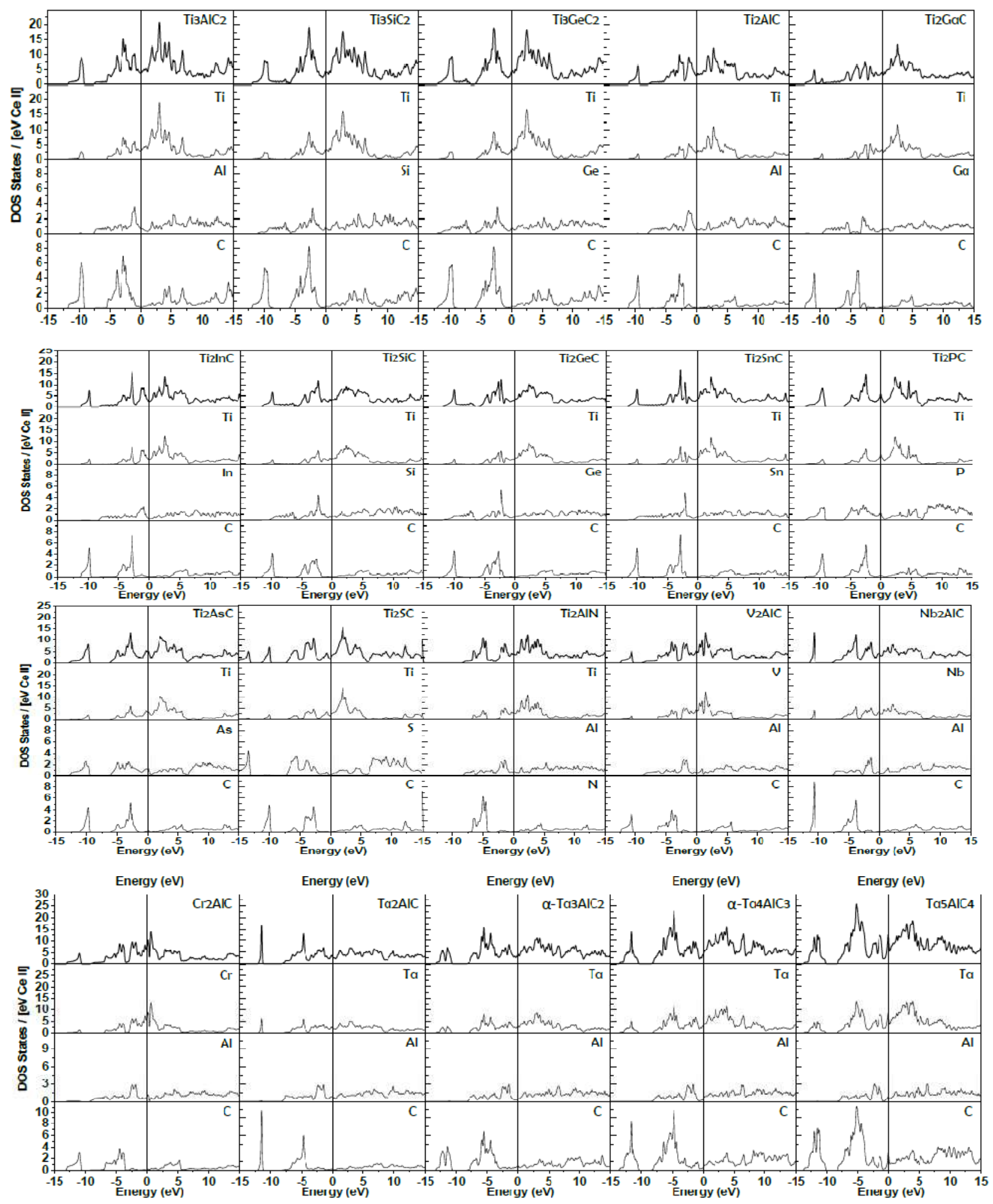

Fig. 4. Calculated DOS and atom-resolved PDOS of 20 MAX phase compounds. 


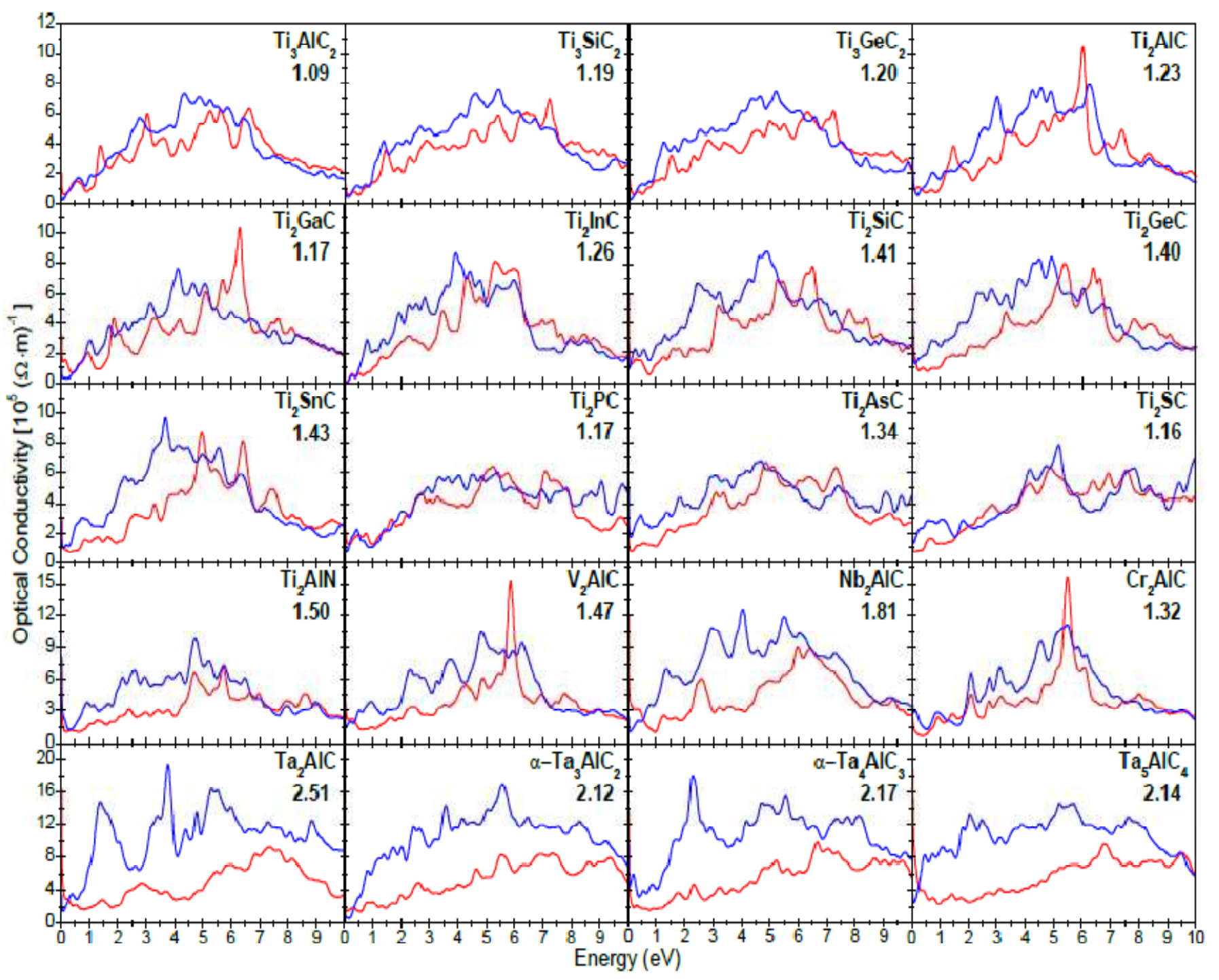

Fig. 5. Optical conductivities of 20 MAX phase compounds. Blue (red) curve show the planer (axial direction)

\section{Comparative Study on Electronic, Optical and Mechanical Properties of MAX Phase Compounds}

\subsection{Electronic and Optical Properties}

The electronic structure and optical conductivities of the MAX phases were calculated using the first-principles orthogonalized linear combination of atomic orbitals (OLCAO) method which is based on the local density approximation (LDA) of density functional theory [58-59]. This method has been demonstrated to be highly accurate and efficient when dealing with materials with complex structures for both crystalline [60-66] and non-crystalline systems [67-71]. Details of the electronic structure and optical conductivity of 20 MAX phase compounds were reported using OLCAO in reference [20].In this review article we studied only some selected results. Fig. 4 shows the total density of states (TDOS) and atom-resolved partial density of states (PDOS) of the 20 MAX phases compounds
The local feature of the total density of states (TDOS) curve around the Fermi-level $\left(E_{f}\right)$ is a reasonable indicator of the intrinsic stability of a crystal. A local minimum at $\mathrm{E}_{f}$ implies higher structural stability because it signifies a barrier for electrons below the $E_{f}(E<0 \mathrm{eV})$ to move into unoccupied empty states $(E>0 \mathrm{eV})$; whereas a local maximum at $E_{f}$ is usually a sign of structural instability. This semiquantitative criterion works reasonably well for the results of Fig. 1. $\mathrm{Ti}_{2} \mathrm{InC}, \mathrm{Ti}_{2} \mathrm{SC}$, and $\mathrm{Cr}_{2} \mathrm{AlC}$ have a local minimum at $\mathrm{E}_{f}$, suggesting a higher level of stability. $\mathrm{Ti}_{2} \mathrm{PC}, \mathrm{Ti}_{2} \mathrm{AsC}$, and $\mathrm{Ta}_{5} \mathrm{AlC}_{4}$ show a peak in the TDOS at $E_{f}$. These facts correlate quite well with the observation that the first group of MAX phases are easier to synthesize whereas those in the second group are not [20]. The calculated optical conductivities in the 20 MAX phase compounds for frequency range between 0 and $10 \mathrm{eV}$ are shown in Fig. 5. The spectra are resolved into two components, one is the planar ( $a-b$ plane) component and the other is the axial ( $c$ direction) component, or $\sigma_{l}$, planar and $\sigma_{l}$, axial for short. The number indicated in each plot is the anisotropy ratio, or the averaged $\left(\sigma_{1 \text {, planar }} / \sigma_{1, \text { axial }}\right)$ ratio over all the data points. 
From these plots, several interesting observations can be made [20]. Most of the MAX phases have the maximum optical conductivities around $5 \mathrm{eV}$ and several phases show sharp peak structures with considerable anisotropy especially in the Ta series. The optical conductivity may be related to the electric conductivity in MAX phases if intraband contribution at the frequency near $0.0 \mathrm{eV}$ can be accounted for. It is conceivable that the anisotropy in optical conductivity in the low energy range could also imply that there may be similar trends in the electrical conductivity. The optical anisotropy in the low energy range of the calculation is quite low for the majority of the 20 phases which correlates well with the low anisotropy in the measured electrical conductivities. A notable exception is $\mathrm{Nb}_{2} \mathrm{AlC}$. Indeed, experiments by T. H. Scabarozi et al. [21] showed that $\mathrm{Nb}_{2} \mathrm{AlC}$ has a significantly larger anisotropy in its electrical conductivity than other MAX-phase compounds.

\subsection{Mechanical and Elastic Properties}

Elastic constants are very important material parameters. Evident and direct application of elastic constants is in the evaluation of elastic strains or energies in materials under stresses of various origins: external, internal and thermal [75]. The elastic constants can also provide information on the stability, stiffness, brittleness, ductility, and anisotropy of a material and propagation of elastic waves and normal mode oscillations. Moreover, knowledge of the values of elastic constants is crucial for a sound understanding of the mechanical properties of the relevant material. The most important parameters for estimating mechanical properties of materials are bulk modulus (B), shear modulus $(G)$, Young's modulus (E) and Poisson's ratio $(v)$. In this section we have studied about these properties. Elastic deformation in crystalline solids is a fully reversible and nondissipative process. For hexagonal symmetry, there are five independent elastic constants; they are $C_{11}, C_{12}, C_{13}, C_{33}$, and $C_{44}$. To date, the nonavailability of large MAX single crystals has made it difficult to experimentally determine their elastic constants. What can be used until such measurements are available, however, are the results of $a b$ initio calculations. In this article all the mechanical properties and elastic constant of MAX phases compounds are summarized and reviewed. All the properties are calculated by using density functional theory (DFT). The bulk moduli $B_{\mathrm{v}}$ and Young's moduli $E_{\mathrm{v}}$ are calculated by using equations 1 and 2. Also the shear moduli $G_{\mathrm{v}}$ and Poisson's ratio $v$ are calculated by using equations $3 \&$ 4.The calculated results for these moduli are listed in table 4.

$$
\begin{gathered}
B_{v}=\frac{2}{9}\left(C_{11}+C_{12}+2 C_{13}+\frac{C_{33}}{2}\right) \\
E_{v}=\frac{9 G_{v} B_{v}}{3 B_{v}+G_{v}} \\
G_{v}=\frac{1}{15}\left(2 C_{11}+C_{33}-C_{12}-2 C_{13}\right)+\frac{1}{5}\left[2 C_{44}+\frac{1}{2}\left(C_{11}-C_{12}\right)\right] \\
v=\frac{3 B_{v}-2 G_{v}}{2\left(3 B_{v}+G_{v}\right)}
\end{gathered}
$$

The Poisson's ratio (S) defined as the ratio of transverse strain to the longitudinal strain is used to reflect the stability of the material against shear and provides information about the nature of the bonding forces. It takes value: $-1<v<1 / 2$. No real material is known to have a negative value of $v$. So this inequality can be replaced with $0<v<1 / 2$. Bigger the Poisson's ratio betters the plasticity. The calculated result of the Poisson's ratio shown in table 4 indicates that the max phase compound is of good plasticity. The $v=0.25$ and $v=$ 0.5 are the lower limit and upper limit for central forces in solids, respectively. The obtained value of Poisson's ratio of $\mathrm{Ta}_{2} \mathrm{GaN}, \mathrm{Cr}_{2} \mathrm{GeC}$ and $\alpha-\mathrm{Ta}_{4} \mathrm{AlC}_{3}$ are larger than the lower limit value, which indicates that the interatomic forces of those compounds are central forces. The bulk modulus is usually assumed to be a measure of resist deformation capacity upon applied pressure [76]. The larger the value of bulk modulus is, the stronger capacity of the resist deformation is. From figure 6 we can make a clear idea about the ability to resist deformation of Max phases. Similarly, the shear moduli are a measure of resist reversible deformation by shear stress [76]. The larger the value is, the stronger capacity of the resist shear deformation is. From Figure 6 we can make a clear idea about this. Furthermore, Young's modulus is defined as the ratio between stress and strain, and it also provided a measure of stiffness of the solid materials. The larger the value is, the stiffer the material is. The calculated result shows that the stiffness of $\beta-\mathrm{Ta}_{4} \mathrm{AlC}_{3}$ is the largest among all Max phases which we studied.

The elastic parameters as presented in Tables 4 allow us to make the following conclusions.

(i) The $\mathrm{C}_{\mathrm{ij}}$ constants for all MAX phases are positive and satisfy the generalized criteria in Ref. [72] for mechanically stable crystals: $\mathrm{C}_{44}>0, \mathrm{C}_{11}>\left|\mathrm{C}_{12}\right|$, and $\left(\mathrm{C}_{11}+\mathrm{C}_{12}\right) \mathrm{C}_{33}>2 \mathrm{C}_{13}^{2}$.

(ii) Among the MAX phases, $\alpha-\mathrm{Ta}_{4} \mathrm{AlC}_{3}$ is the phase with the largest bulk modulus ( $266 \mathrm{GPa})$, while $\mathrm{Ti}_{2} \mathrm{CdC}$ has the smallest $\mathrm{B}_{\mathrm{v}} \sim 115.66 \mathrm{GPa}$. We have also seen that $\beta-\mathrm{Ta}_{4} \mathrm{AlC}_{3}$ has maximum Young's modulus ( 404) $\mathrm{GPa}$ where $\mathrm{Ti}_{2} \mathrm{CdC}$ and $\mathrm{Zr}_{2} \mathrm{PbC}$ have the smallest $E_{\mathrm{v}} \sim 174 \mathrm{GPa}$.

(iii) The Young's modulus is defined as the ratio between stress and strain and is used to provide a measure of stiffness, i.e., the larger the value of $E_{\mathrm{v}}$, the stiffer the material. In our case $\beta-\mathrm{Ta}_{4} \mathrm{AlC}_{3}>\alpha-\mathrm{V}_{4} \mathrm{AlC}_{3}>\mathrm{V}_{2} \mathrm{PC}>\alpha-$ $\mathrm{Ta}_{4} \mathrm{AlC}_{3}>\mathrm{Ti}_{4} \mathrm{AlN}_{3}>\alpha-\mathrm{Nb}_{4} \mathrm{AlC}_{3}>\mathrm{Cr}_{2} \mathrm{AlC}>\mathrm{Ti}_{3} \mathrm{GeC}_{2}>$ $\mathrm{Ti}_{4} \mathrm{GeC}_{3}>\mathrm{Hf}_{2} \mathrm{SC}>\mathrm{Nb}_{2} \mathrm{PC}>\mathrm{Ta}_{4} \mathrm{GaC}_{3}>\mathrm{V}_{2} \mathrm{GaC}>$ $\mathrm{V}_{2} \mathrm{AlC} \ldots \ldots \ldots \ldots . . . . \mathrm{Hf}_{2} \mathrm{PbC}>\mathrm{Ti}_{2} \mathrm{PbC}>\mathrm{Zr}_{2} \mathrm{PbC}$ (see details in Table 5).The maximum and minimum shear moduli are obtained in $\mathrm{Ti}_{4} \mathrm{AlN}_{3}$ and $\mathrm{Zr}_{2} \mathrm{PbC}$. The ascending to descending values of bulk modulus $\left(B_{\mathrm{v}}\right)$, Young's modulus $\left(E_{\mathrm{v}}\right)$, shear modulus $\left(G_{\mathrm{v}}\right)$ and Possion's ratio of all the MAX phases compounds are shown in details in Table 5.

(iv) Poisson's ratios for most of the MAX phases are around 0.2 (Table 4), which is lower than the 0.3 of Ti and most metals, and closer to the 0.19 of near-stoichiometric TiC. According to Pugh's criteria [73], a material should behave in a ductile manner if $\mathrm{G} / \mathrm{B}<0.5$, otherwise it should be brittle. In our case, all the compounds have $\mathrm{G} / \mathrm{B}<0.5$, (Table 5) therefore all the MAX phases compounds show ductile behavior. 
Table 4. Summary of 50 MAX phase compounds, elastic constants $C_{i j}$ determined from ab-initio calculations. Also the values of $B_{v}, E_{v}, G_{v}$, and $v$ are listed calculated using Equations 1, 2, 3 \& 4 respectively.

\begin{tabular}{|c|c|c|c|c|c|c|c|c|c|c|}
\hline Compounds & $C_{11}$ & $C_{12}$ & $C_{13}$ & $C_{33}$ & $C_{44}$ & $B_{\mathrm{v}}$ & $E_{\mathrm{v}}$ & $G_{\mathrm{v}}$ & $v$ & Ref. \\
\hline & & & & 413 Phases & & & & & & \\
\hline $\mathrm{Ti}_{4} \mathrm{AlN}_{3}$ & 420 & 73 & 70 & 380 & 128 & 182.88 & 359 & 153 & 0.172 & 36 \\
\hline $\mathrm{Ti}_{4} \mathrm{GeC}_{3}$ & 381 & 96 & 95 & 349 & 148 & 187.00 & 341 & 143 & 0.195 & 37 \\
\hline$\alpha-\mathrm{Ta}_{4} \mathrm{AlC}_{3}$ & 437 & 158 & 197 & 416 & 165 & 266.00 & 364 & 143 & 0.272 & 38 \\
\hline$\beta-\mathrm{Ta}_{4} \mathrm{AlC}_{3}$ & 509 & 143 & 156 & 440 & 147 & 263.11 & 404 & 162 & 0.244 & 39 \\
\hline $\mathrm{Ta}_{4} \mathrm{GaC}_{3}$ & 389 & 84 & 78 & 323 & 131 & 175.66 & 332 & 140 & 0.185 & 40 \\
\hline$\alpha-\mathrm{V}_{4} \mathrm{AlC}_{3}$ & 435 & 121 & 105 & 384 & 168 & 212.88 & 384 & 160 & 0.199 & 39 \\
\hline \multirow{2}{*}{$\alpha-\mathrm{Nb}_{4} \mathrm{AlC}_{3}$} & 413 & 124 & 135 & 328 & 161 & 215.77 & 353 & 144 & 0.227 & 39 \\
\hline & & & & 312 Phases & & & & & & \\
\hline $\mathrm{Ti}_{3} \mathrm{SiC}_{2}$ & 365 & 125 & 120 & 375 & 122 & 203.88 & 307 & 123 & 0.248 & 42 \\
\hline $\mathrm{Ti}_{3} \mathrm{GeC}_{2}$ & 355 & 143 & 80 & 404 & 172 & 191.11 & 345 & 144 & 0.198 & 43 \\
\hline $\mathrm{Ti}_{3} \mathrm{AlC}_{2}$ & 361 & 75 & 70 & 299 & 124 & 161.22 & 321 & 132 & 0.178 & 44 \\
\hline \multirow[t]{2}{*}{$\mathrm{Ti}_{3} \mathrm{SnC}_{2}$} & 346 & 92 & 84 & 313 & 123 & 169.44 & 300 & 124 & 0.205 & 41 \\
\hline & & & & 211 Phases & & & & & & \\
\hline $\mathrm{Ti}_{2} \mathrm{AlN}$ & 342 & 56 & 96 & 283 & 123 & 162.55 & 300 & 126 & 0.192 & 36 \\
\hline $\mathrm{Ti}_{2} \mathrm{AlC}$ & 301 & 59 & 55 & 278 & 113 & 135.33 & 272 & 117 & 0.164 & 45 \\
\hline $\mathrm{Ti}_{2} \mathrm{SnC}$ & 260 & 78 & 70 & 254 & 93 & 134.44 & 226 & 93 & 0.218 & 54 \\
\hline $\mathrm{Ti}_{2} \mathrm{GeC}$ & 279 & 99 & 95 & 283 & 125 & 157.66 & 257 & 105 & 0.227 & 48 \\
\hline $\mathrm{Ti}_{2} \mathrm{GaC}$ & 314 & 66 & 59 & 272 & 122 & 140.88 & 283 & 121 & 0.166 & 49 \\
\hline $\mathrm{Ti}_{2} \mathrm{SC}$ & 315 & 98 & 99 & 362 & 161 & 176.00 & 310 & 127 & 0.209 & 46 \\
\hline $\mathrm{Ti}_{2} \mathrm{CdC}$ & 258 & 68 & 46 & 205 & 33 & 115.66 & 174 & 69.6 & 0.249 & 53 \\
\hline $\mathrm{Ti}_{2} \mathrm{InC}$ & 288 & 62 & 53 & 248 & 88 & 128.88 & 241 & 102 & 0.186 & 53 \\
\hline $\mathrm{Ti}_{2} \operatorname{InN}$ & 229 & 56 & 106 & 248 & 92 & 138.00 & 208 & 83.3 & 0.248 & 54 \\
\hline $\mathrm{Ti}_{2} \mathrm{PbC}$ & 235 & 90 & 53 & 211 & 66 & 119.22 & 182 & 73.2 & 0.245 & 54 \\
\hline $\mathrm{V}_{2} \mathrm{AlC}$ & 346 & 71 & 106 & 314 & 151 & 174.66 & 324 & 136 & 0.190 & 51 \\
\hline $\mathrm{V}_{2} \mathrm{GeC}$ & 282 & 121 & 95 & 259 & 160 & 160.55 & 277 & 114 & 0.212 & 47 \\
\hline $\mathrm{V}_{2} \mathrm{GaC}$ & 343 & 67 & 124 & 312 & 157 & 180.88 & 326 & 136 & 0.199 & 49 \\
\hline $\mathrm{V}_{2} \mathrm{GaN}$ & 281 & 71 & 142 & 293 & 128 & 173.88 & 263 & 106 & 0.246 & 54 \\
\hline $\mathrm{V}_{2} \mathrm{AsC}$ & 334 & 109 & 157 & 321 & 170 & 203.88 & 318 & 128 & 0.240 & 57 \\
\hline $\mathrm{V}_{2} \mathrm{PC}$ & 376 & 113 & 168 & 386 & 204 & 226.22 & 376 & 154 & 0.222 & 54 \\
\hline $\mathrm{Cr}_{2} \mathrm{AlC}$ & 384 & 79 & 107 & 382 & 147 & 192.88 & 351 & 146 & 0.197 & 52 \\
\hline $\mathrm{Cr}_{2} \mathrm{GeC}$ & 315 & 99 & 146 & 354 & 89 & 196.22 & 249 & 96.7 & 0.288 & 47 \\
\hline $\mathrm{Cr}_{2} \mathrm{GaC}$ & 312 & 81 & 139 & 325 & 128 & 185.22 & 283 & 114 & 0.244 & 54 \\
\hline $\mathrm{Mo}_{2} \mathrm{GaC}$ & 294 & 98 & 107 & 289 & 127 & 166.77 & 257 & 111 & 0.227 & 54 \\
\hline $\mathrm{Nb}_{2} \mathrm{AlC}$ & 310 & 90 & 118 & 289 & 139 & 173.44 & 285 & 116 & 0.226 & 54 \\
\hline $\mathrm{Nb}_{2} \mathrm{GaC}$ & 309 & 80 & 138 & 262 & 126 & 176.88 & 270 & 108 & 0.246 & 54 \\
\hline $\mathrm{Nb}_{2} \mathrm{SnC}$ & 341 & 106 & 169 & 321 & 183 & 210.11 & 314 & 134 & 0.237 & 56 \\
\hline $\mathrm{Nb}_{2} \operatorname{InC}$ & 291 & 76 & 108 & 267 & 102 & 159.22 & 247 & 99.4 & 0.241 & 54 \\
\hline $\mathrm{Nb}_{2} \mathrm{AsC}$ & 334 & 104 & 169 & 331 & 167 & 209.22 & 317 & 127 & 0.247 & 57 \\
\hline $\mathrm{Nb}_{2} \mathrm{PC}$ & 369 & 113 & 171 & 316 & 170 & 218.22 & 333 & 134 & 0.245 & 54 \\
\hline $\mathrm{Hf}_{2} \mathrm{SC}$ & 344 & 116 & 138 & 369 & 175 & 204.55 & 336 & 137 & 0.226 & 50 \\
\hline $\mathrm{Hf}_{2} \mathrm{SnC}$ & 318 & 96 & 99 & 301 & 123 & 169.44 & 280 & 114 & 0.225 & 55 \\
\hline $\mathrm{Hf}_{2} \mathrm{SnN}$ & 240 & 62 & 103 & 236 & 92 & 139.11 & 211 & 84.5 & 0.247 & 54 \\
\hline $\mathrm{Hf}_{2} \operatorname{InC}$ & 284 & 69 & 65 & 243 & 91 & 134.33 & 238 & 98.7 & 0.204 & 57 \\
\hline $\mathrm{Hf}_{2} \mathrm{PbC}$ & 241 & 77 & 70 & 222 & 69 & 126.44 & 191 & 81 & 0.236 & 54 \\
\hline $\mathrm{Ta}_{2} \mathrm{AlC}$ & 334 & 114 & 130 & 322 & 148 & 193.11 & 303 & 122 & 0.239 & 54 \\
\hline $\mathrm{Ta}_{2} \mathrm{GaC}$ & 335 & 106 & 137 & 315 & 137 & 193.88 & 294 & 118 & 0.247 & 54 \\
\hline $\mathrm{Ta}_{2} \mathrm{GaN}$ & 333 & 187 & 150 & 364 & 141 & 222.66 & 277 & 107 & 0.292 & 54 \\
\hline $\mathrm{Zr}_{2} \mathrm{SnC}$ & 279 & 92 & 97 & 272 & 111 & 155.77 & 252 & 104 & 0.226 & 48 \\
\hline $\mathrm{Zr}_{2} \mathrm{SC}$ & 326 & 103 & 119 & 351 & 160 & 187.22 & 318 & 130 & 0.218 & 50 \\
\hline $\mathrm{Zr}_{2} \operatorname{InC}$ & 251 & 62 & 58 & 215 & 73 & 119.22 & 204 & 84 & 0.214 & 54 \\
\hline $\mathrm{Zr}_{2} \operatorname{InN}$ & 241 & 71 & 89 & 223 & 85 & 133.66 & 203 & 81.4 & 0.246 & 54 \\
\hline $\mathrm{Zr}_{2} \mathrm{PbC}$ & 219 & 70 & 67 & 206 & 68 & 116.88 & 174 & 71.4 & 0.246 & 54 \\
\hline
\end{tabular}




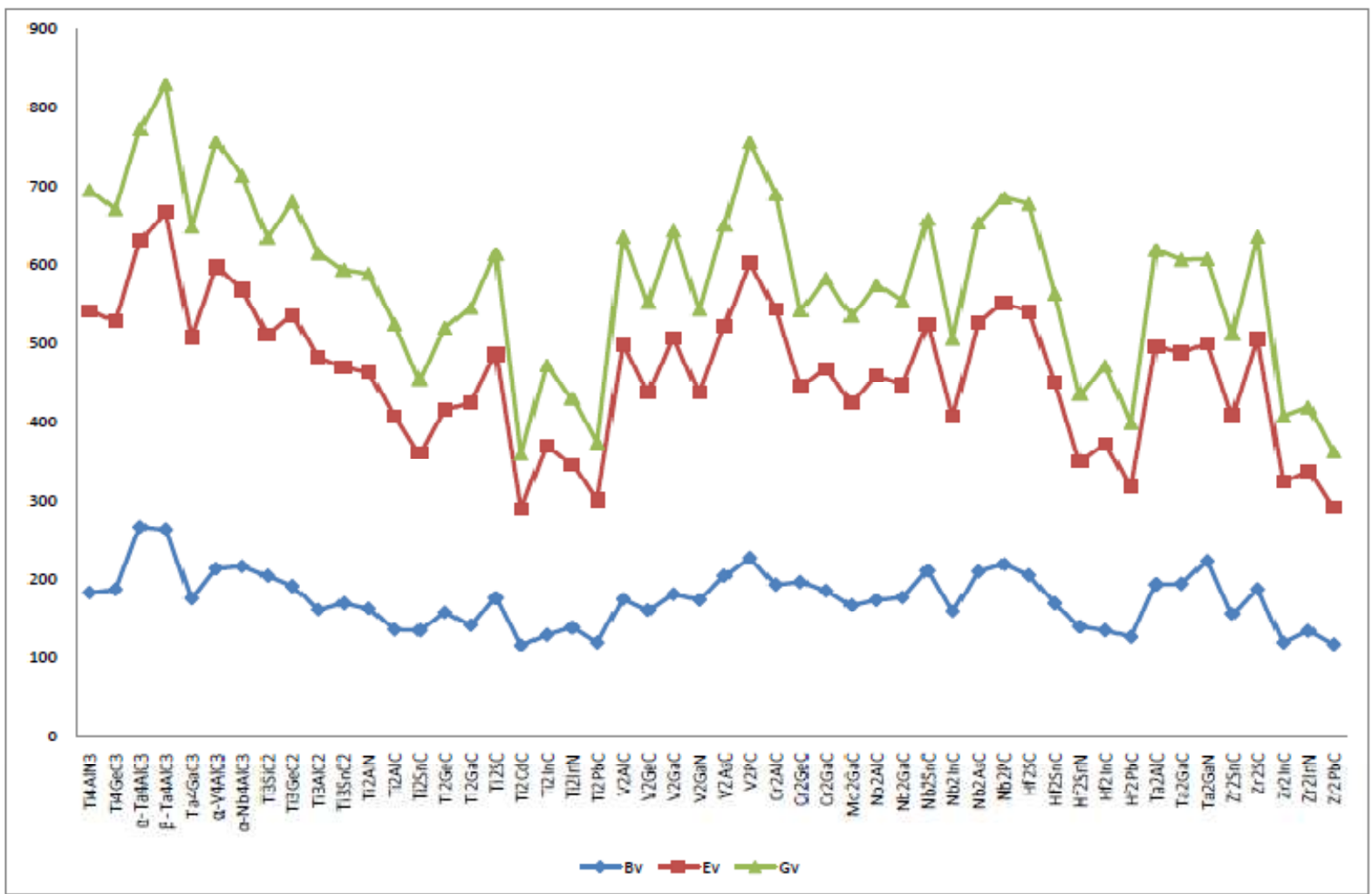

Fig. 6. Bulk moduli $\left(B_{v}\right)$, shear moduli $\left(G_{v}\right)$ and Young's moduli $\left(E_{v}\right)$ of 50 Max Phases.

Table 5. Ascending to descending values of bulk modulus $\left(B_{v}\right)$, Young's modulus $\left(E_{v}\right)$, shear modulus $\left(G_{v}\right)$ and Possion's ratio of all the MAX phase compounds.

\begin{tabular}{|c|c|c|c|c|c|c|c|}
\hline Compounds & $B_{\mathrm{v}}$ & Compounds & $E_{\mathrm{v}}$ & Compounds & $G_{\mathrm{v}}$ & Compounds & $v$ \\
\hline$\alpha-\mathrm{Ta}_{4} \mathrm{AlC}_{3}$ & 266 & $\beta-\mathrm{Ta}_{4} \mathrm{AlC}_{3}$ & 404 & $\beta-\mathrm{Ta}_{4} \mathrm{AlC}_{3}$ & 162 & $\mathrm{Ta}_{2} \mathrm{GaN}$ & 0.292 \\
\hline$\beta-\mathrm{Ta}_{4} \mathrm{AlC}_{3}$ & 263.11 & $\alpha-\mathrm{V}_{4} \mathrm{AlC}_{3}$ & 384 & $\alpha-\mathrm{V}_{4} \mathrm{AlC}_{3}$ & 160 & $\mathrm{Cr}_{2} \mathrm{GeC}$ & 0.288 \\
\hline $\mathrm{V}_{2} \mathrm{PC}$ & 226.22 & $\mathrm{~V}_{2} \mathrm{PC}$ & 376 & $\mathrm{~V}_{2} \mathrm{PC}$ & 154 & $\alpha-\mathrm{Ta}_{4} \mathrm{AlC}_{3}$ & 0.272 \\
\hline $\mathrm{Ta}_{2} \mathrm{GaN}$ & 222.66 & $\alpha-\mathrm{Ta}_{4} \mathrm{AlC}_{3}$ & 364 & $\mathrm{Ti}_{4} \mathrm{AlN}_{3}$ & 153 & $\mathrm{Ti}_{2} \mathrm{CdC}$ & 0.249 \\
\hline $\mathrm{Nb}_{2} \mathrm{PC}$ & 218.22 & $\mathrm{Ti}_{4} \mathrm{AlN}_{3}$ & 359 & $\mathrm{Cr}_{2} \mathrm{AlC}$ & 146 & $\mathrm{Ti}_{3} \mathrm{SiC}_{2}$ & 0.248 \\
\hline$\alpha-\mathrm{Nb}_{4} \mathrm{AlC}_{3}$ & 215.77 & $\alpha-\mathrm{Nb}_{4} \mathrm{AlC}_{3}$ & 353 & $\alpha-\mathrm{Nb}_{4} \mathrm{AlC}_{3}$ & 144 & $\mathrm{Ti}_{2} \operatorname{InN}$ & 0.248 \\
\hline$\alpha-\mathrm{V}_{4} \mathrm{AlC}_{3}$ & 212.88 & $\mathrm{Cr}_{2} \mathrm{AlC}$ & 351 & $\mathrm{Ti}_{3} \mathrm{GeC}_{2}$ & 144 & $\mathrm{Nb}_{2} \mathrm{AsC}$ & 0.247 \\
\hline $\mathrm{Nb}_{2} \mathrm{SnC}$ & 210.11 & $\mathrm{Ti}_{3} \mathrm{GeC}_{2}$ & 345 & $\mathrm{Ti}_{4} \mathrm{GeC}_{3}$ & 143 & $\mathrm{Hf}_{2} \mathrm{SnN}$ & 0.247 \\
\hline $\mathrm{Nb}_{2} \mathrm{AsC}$ & 209.22 & $\mathrm{Ti}_{4} \mathrm{GeC}_{3}$ & 341 & $\alpha-\mathrm{Ta}_{4} \mathrm{AlC}_{3}$ & 143 & $\mathrm{Ta}_{2} \mathrm{GaC}$ & 0.247 \\
\hline $\mathrm{Hf}_{2} \mathrm{SC}$ & 204.55 & $\mathrm{Hf}_{2} \mathrm{SC}$ & 336 & $\mathrm{Ta}_{4} \mathrm{GaC}_{3}$ & 140 & $\mathrm{~V}_{2} \mathrm{GaN}$ & 0.246 \\
\hline $\mathrm{Ti}_{3} \mathrm{SiC}_{2}$ & 203.88 & $\mathrm{Nb}_{2} \mathrm{PC}$ & 333 & $\mathrm{Hf}_{2} \mathrm{SC}$ & 137 & $\mathrm{Nb}_{2} \mathrm{GaC}$ & 0.246 \\
\hline $\mathrm{V}_{2} \mathrm{AsC}$ & 203.88 & $\mathrm{Ta}_{4} \mathrm{GaC}_{3}$ & 332 & $\mathrm{~V}_{2} \mathrm{AlC}$ & 136 & $\mathrm{Zr}_{2} \operatorname{InN}$ & 0.246 \\
\hline $\mathrm{Cr}_{2} \mathrm{GeC}$ & 196.22 & $\mathrm{~V}_{2} \mathrm{GaC}$ & 326 & $\mathrm{~V}_{2} \mathrm{GaC}$ & 136 & $\mathrm{Zr}_{2} \mathrm{PbC}$ & 0.246 \\
\hline $\mathrm{Ta}_{2} \mathrm{GaC}$ & 193.88 & $\mathrm{~V}_{2} \mathrm{AlC}$ & 324 & $\mathrm{Nb}_{2} \mathrm{SnC}$ & 134 & $\mathrm{Ti}_{2} \mathrm{PbC}$ & 0.245 \\
\hline $\mathrm{Ta}_{2} \mathrm{AlC}$ & 193.11 & $\mathrm{Ti}_{3} \mathrm{AlC}_{2}$ & 321 & $\mathrm{Nb}_{2} \mathrm{PC}$ & 134 & $\mathrm{Nb}_{2} \mathrm{PC}$ & 0.245 \\
\hline $\mathrm{Cr}_{2} \mathrm{AlC}$ & 192.88 & $\mathrm{~V}_{2} \mathrm{AsC}$ & 318 & $\mathrm{Ti}_{3} \mathrm{AlC}_{2}$ & 132 & $\beta-\mathrm{Ta}_{4} \mathrm{AlC}_{3}$ & 0.244 \\
\hline $\mathrm{Ti}_{3} \mathrm{GeC}_{2}$ & 191.11 & $\mathrm{Zr}_{2} \mathrm{SC}$ & 318 & $\mathrm{Zr}_{2} \mathrm{SC}$ & 130 & $\mathrm{Cr}_{2} \mathrm{GaC}$ & 0.244 \\
\hline $\mathrm{Zr}_{2} \mathrm{SC}$ & 187.22 & $\mathrm{Nb}_{2} \mathrm{AsC}$ & 317 & $\mathrm{~V}_{2} \mathrm{AsC}$ & 128 & $\mathrm{Nb}_{2} \mathrm{InC}$ & 0.241 \\
\hline $\mathrm{Ti}_{4} \mathrm{GeC}_{3}$ & 187 & $\mathrm{Nb}_{2} \mathrm{SnC}$ & 314 & $\mathrm{Ti}_{2} \mathrm{SC}$ & 127 & $\mathrm{~V}_{2} \mathrm{AsC}$ & 0.24 \\
\hline $\mathrm{Cr}_{2} \mathrm{GaC}$ & 185.22 & $\mathrm{Ti}_{2} \mathrm{SC}$ & 310 & $\mathrm{Nb}_{2} \mathrm{AsC}$ & 127 & $\mathrm{Ta}_{2} \mathrm{AlC}$ & 0.239 \\
\hline $\mathrm{Ti}_{4} \mathrm{AlN}_{3}$ & 182.88 & $\mathrm{Ti}_{3} \mathrm{SiC}_{2}$ & 307 & $\mathrm{Ti}_{2} \mathrm{AlN}$ & 126 & $\mathrm{Nb}_{2} \mathrm{SnC}$ & 0.237 \\
\hline $\mathrm{V}_{2} \mathrm{GaC}$ & 180.88 & $\mathrm{Ta}_{2} \mathrm{AlC}$ & 303 & $\mathrm{Ti}_{3} \mathrm{SnC}_{2}$ & 124 & $\mathrm{Hf}_{2} \mathrm{PbC}$ & 0.236 \\
\hline $\mathrm{Nb}_{2} \mathrm{GaC}$ & 176.88 & $\mathrm{Ti}_{3} \mathrm{SnC}_{2}$ & 300 & $\mathrm{Ti}_{3} \mathrm{SiC}_{2}$ & 123 & $\alpha-\mathrm{Nb}_{4} \mathrm{AlC}_{3}$ & 0.227 \\
\hline $\mathrm{Ti}_{2} \mathrm{SC}$ & 176 & $\mathrm{Ti}_{2} \mathrm{AlN}$ & 300 & $\mathrm{Ta}_{2} \mathrm{AlC}$ & 122 & $\mathrm{Ti}_{2} \mathrm{GeC}$ & 0.227 \\
\hline $\mathrm{Ta}_{4} \mathrm{GaC}_{3}$ & 175.66 & $\mathrm{Ta}_{2} \mathrm{GaC}$ & 294 & $\mathrm{Ti}_{2} \mathrm{GaC}$ & 121 & $\mathrm{Mo}_{2} \mathrm{GaC}$ & 0.227 \\
\hline $\mathrm{V}_{2} \mathrm{AlC}$ & 174.66 & $\mathrm{Nb}_{2} \mathrm{AlC}$ & 285 & $\mathrm{Ta}_{2} \mathrm{GaC}$ & 118 & $\mathrm{Nb}_{2} \mathrm{AlC}$ & 0.226 \\
\hline
\end{tabular}




\begin{tabular}{|c|c|c|c|c|c|c|c|}
\hline Compounds & $B_{\mathrm{v}}$ & Compounds & $E_{\mathrm{v}}$ & Compounds & $G_{\mathrm{v}}$ & Compounds & $v$ \\
\hline $\mathrm{V}_{2} \mathrm{GaN}$ & 173.88 & $\mathrm{Ti}_{2} \mathrm{GaC}$ & 283 & $\mathrm{Ti}_{2} \mathrm{AlC}$ & 117 & $\mathrm{Hf}_{2} \mathrm{SC}$ & 0.226 \\
\hline $\mathrm{Nb}_{2} \mathrm{AlC}$ & 173.44 & $\mathrm{Cr}_{2} \mathrm{GaC}$ & 283 & $\mathrm{Nb}_{2} \mathrm{AlC}$ & 116 & $\mathrm{Zr}_{2} \mathrm{SnC}$ & 0.226 \\
\hline $\mathrm{Ti}_{3} \mathrm{SnC}_{2}$ & 169.44 & $\mathrm{Hf}_{2} \mathrm{SnC}$ & 280 & $\mathrm{~V}_{2} \mathrm{GeC}$ & 114 & $\mathrm{Hf}_{2} \mathrm{SnC}$ & 0.225 \\
\hline $\mathrm{Hf}_{2} \mathrm{SnC}$ & 169.44 & $\mathrm{~V}_{2} \mathrm{GeC}$ & 277 & $\mathrm{Cr}_{2} \mathrm{GaC}$ & 114 & $\mathrm{~V}_{2} \mathrm{PC}$ & 0.222 \\
\hline $\mathrm{Mo}_{2} \mathrm{GaC}$ & 166.77 & $\mathrm{Ta}_{2} \mathrm{GaN}$ & 277 & $\mathrm{Hf}_{2} \mathrm{SnC}$ & 114 & $\mathrm{Ti}_{2} \mathrm{SnC}$ & 0.218 \\
\hline $\mathrm{Ti}_{2} \mathrm{AlN}$ & 162.55 & $\mathrm{Ti}_{2} \mathrm{AlC}$ & 272 & $\mathrm{Mo}_{2} \mathrm{GaC}$ & 111 & $\mathrm{Zr}_{2} \mathrm{SC}$ & 0.218 \\
\hline $\mathrm{Ti}_{3} \mathrm{AlC}_{2}$ & 161.22 & $\mathrm{Nb}_{2} \mathrm{GaC}$ & 270 & $\mathrm{Nb}_{2} \mathrm{GaC}$ & 108 & $\mathrm{Zr}_{2} \mathrm{InC}$ & 0.214 \\
\hline $\mathrm{V}_{2} \mathrm{GeC}$ & 160.55 & $\mathrm{~V}_{2} \mathrm{GaN}$ & 263 & $\mathrm{Ta}_{2} \mathrm{GaN}$ & 107 & $\mathrm{~V}_{2} \mathrm{GeC}$ & 0.212 \\
\hline $\mathrm{Nb}_{2} \mathrm{InC}$ & 159.22 & $\mathrm{Ti}_{2} \mathrm{GeC}$ & 257 & $\mathrm{~V}_{2} \mathrm{GaN}$ & 106 & $\mathrm{Ti}_{2} \mathrm{SC}$ & 0.209 \\
\hline $\mathrm{Ti}_{2} \mathrm{GeC}$ & 157.66 & $\mathrm{Mo}_{2} \mathrm{GaC}$ & 257 & $\mathrm{Ti}_{2} \mathrm{GeC}$ & 105 & $\mathrm{Ti}_{3} \mathrm{SnC}_{2}$ & 0.205 \\
\hline $\mathrm{Zr}_{2} \mathrm{SnC}$ & 155.77 & $\mathrm{Zr}_{2} \mathrm{SnC}$ & 252 & $\mathrm{Zr}_{2} \mathrm{SnC}$ & 104 & $\mathrm{Hf}_{2} \operatorname{InC}$ & 0.204 \\
\hline $\mathrm{Ti}_{2} \mathrm{GaC}$ & 140.88 & $\mathrm{Cr}_{2} \mathrm{GeC}$ & 249 & $\mathrm{Ti}_{2} \operatorname{InC}$ & 102 & $\alpha-\mathrm{V}_{4} \mathrm{AlC}_{3}$ & 0.199 \\
\hline $\mathrm{Hf}_{2} \mathrm{SnN}$ & 139.11 & $\mathrm{Nb}_{2} \operatorname{InC}$ & 247 & $\mathrm{Nb}_{2} \operatorname{InC}$ & 99.4 & $\mathrm{~V}_{2} \mathrm{GaC}$ & 0.199 \\
\hline $\mathrm{Ti}_{2} \mathrm{InN}$ & 138 & $\mathrm{Ti}_{2} \mathrm{InC}$ & 241 & $\mathrm{Hf}_{2} \mathrm{InC}$ & 98.7 & $\mathrm{Ti}_{3} \mathrm{GeC}_{2}$ & 0.198 \\
\hline $\mathrm{Ti}_{2} \mathrm{AlC}$ & 135.33 & $\mathrm{Hf}_{2} \operatorname{InC}$ & 238 & $\mathrm{Cr}_{2} \mathrm{GeC}$ & 96.7 & $\mathrm{Cr}_{2} \mathrm{AlC}$ & 0.197 \\
\hline $\mathrm{Ti}_{2} \mathrm{SnC}$ & 134.44 & $\mathrm{Ti}_{2} \mathrm{SnC}$ & 226 & $\mathrm{Ti}_{2} \mathrm{SnC}$ & 93 & $\mathrm{Ti}_{4} \mathrm{GeC}_{3}$ & 0.195 \\
\hline $\mathrm{Hf}_{2} \operatorname{InC}$ & 134.33 & $\mathrm{Hf}_{2} \mathrm{SnN}$ & 211 & $\mathrm{Hf}_{2} \mathrm{SnN}$ & 84.5 & $\mathrm{Ti}_{2} \mathrm{AlN}$ & 0.192 \\
\hline $\mathrm{Zr}_{2} \operatorname{InN}$ & 133.66 & $\mathrm{Ti}_{2} \mathrm{InN}$ & 208 & $\mathrm{Zr}_{2} \operatorname{InC}$ & 84 & $\mathrm{~V}_{2} \mathrm{AlC}$ & 0.19 \\
\hline $\mathrm{Ti}_{2} \mathrm{InC}$ & 128.88 & $\mathrm{Zr}_{2} \operatorname{InC}$ & 204 & $\mathrm{Ti}_{2} \operatorname{InN}$ & 83.3 & $\mathrm{Ti}_{2} \mathrm{InC}$ & 0.186 \\
\hline $\mathrm{Hf}_{2} \mathrm{PbC}$ & 126.44 & $\mathrm{Zr}_{2} \operatorname{InN}$ & 203 & $\mathrm{Zr}_{2} \operatorname{InN}$ & 81.4 & $\mathrm{Ta}_{4} \mathrm{GaC}_{3}$ & 0.185 \\
\hline $\mathrm{Ti}_{2} \mathrm{PbC}$ & 119.22 & $\mathrm{Hf}_{2} \mathrm{PbC}$ & 191 & $\mathrm{Hf}_{2} \mathrm{PbC}$ & 81 & $\mathrm{Ti}_{3} \mathrm{AlC}_{2}$ & 0.178 \\
\hline $\mathrm{Zr}_{2} \operatorname{InC}$ & 119.22 & $\mathrm{Ti}_{2} \mathrm{PbC}$ & 182 & $\mathrm{Ti}_{2} \mathrm{PbC}$ & 73.2 & $\mathrm{Ti}_{4} \mathrm{AlN}_{3}$ & 0.172 \\
\hline $\mathrm{Zr}_{2} \mathrm{PbC}$ & 116.88 & $\mathrm{Ti}_{2} \mathrm{CdC}$ & 174 & $\mathrm{Zr}_{2} \mathrm{PbC}$ & 71.4 & $\mathrm{Ti}_{2} \mathrm{GaC}$ & 0.166 \\
\hline $\mathrm{Ti}_{2} \mathrm{CdC}$ & 115.66 & $\mathrm{Zr}_{2} \mathrm{PbC}$ & 174 & $\mathrm{Ti}_{2} \mathrm{CdC}$ & 69.6 & $\mathrm{Ti}_{2} \mathrm{AlC}$ & 0.164 \\
\hline
\end{tabular}

\section{MAX Phase Potential Applications}

The MAX phases have been proposed for numerous applications, some of which are discussed briefly below. The purpose of this section is mostly to show the rich potential for applications and the range of industries that the MAX phases could in principle impact.

\subsection{Replacement for Graphite at High Temperatures}

Graphite is an important high-temperature material used extensively in many industries. For example, graphite is used as connectors, heaters, furnace linings, shields, rigid insulation, curved heating elements, and fasteners in vacuum furnaces. Graphite is also the material of choice for the hot pressing of diamond-cutting tools and other materials, for the construction industry. In general, some of the MAX phases such as $\mathrm{Ti}_{2} \mathrm{AlC}$ have several advantages over graphite such as better wear and oxidation resistance. The ease by which $\mathrm{Ti}_{2} \mathrm{AlC}$ can be machined to high tolerances is also an important consideration. The high strengths, moduli, and thermal conductivities of the MAX phases are also positive attributes. Figure 7 shows examples of MAX phase inserts that were actually tested in industrial dies and performed quite well.
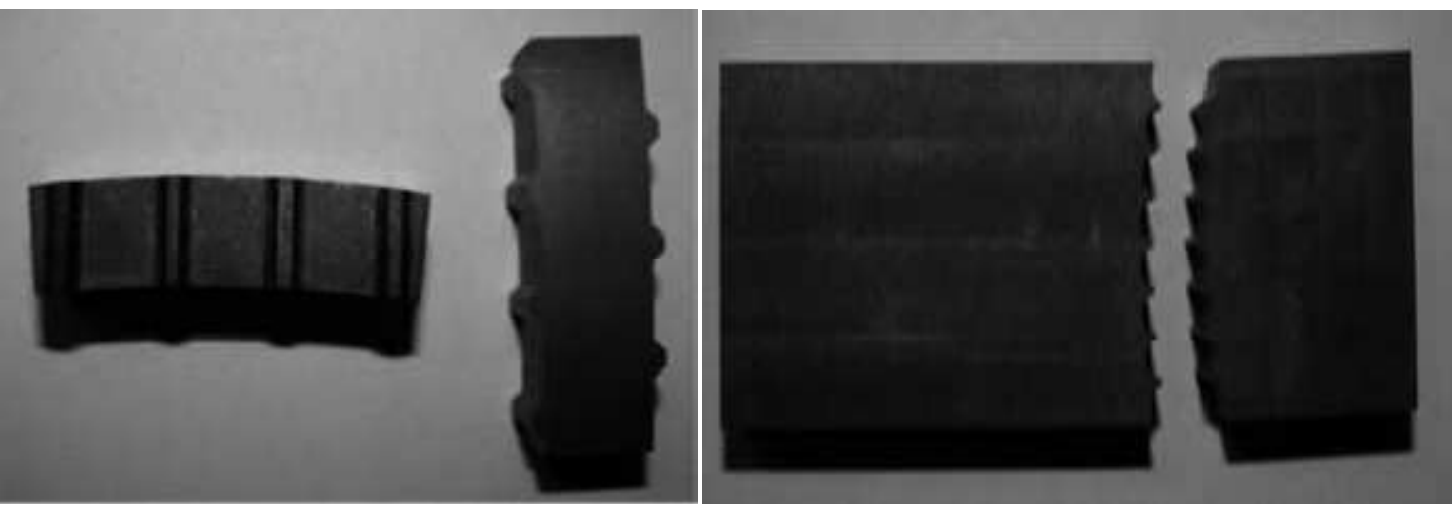

(a)(b)

Fig. 7. (a, b) MAX-based insets that were tested in industrial dies at elevated temperatures. (Courtesy of 3-ONE-2, LLC.). 


\subsection{Heating Elements}

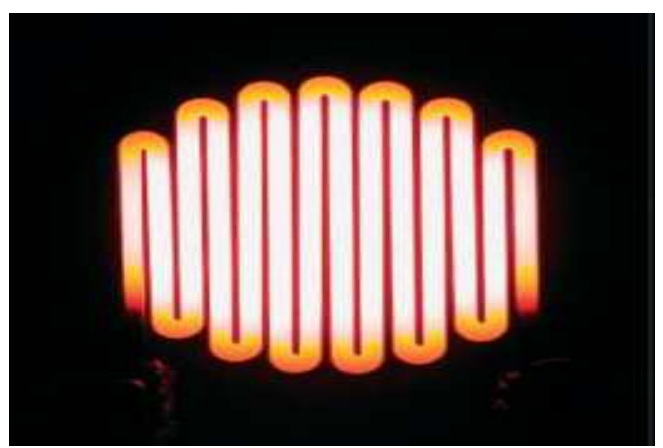

Fig. 8. Example of $T_{2} A l C$-based heating element resistively heated to 1450 ${ }^{0} \mathrm{C}$ in air (Courtesy of Kanthal).

In the late 1990s, Kanthal Corp. licensed the MAX technology from Drexel University. Given that one of Kanthal's core businesses is heating elements, it was not surprising that MAX phase heating elements were one of the first applications targeted by the Swedish company. The heating element shown in figure 8 was heated up to $1350{ }^{\circ} \mathrm{C}$ and cooled down to room temperature for $\approx 10000$ cycles (Sundberg et al., 2004). The resistance of the element was found to be very stable and the protective oxide that formed was quite adherent and protective. This heating element is quite versatile and can be used up to $1400{ }^{\circ} \mathrm{C}$ in air, argon, hydrogen, or vacuum.

\subsection{High-Temperature Foil Bearings and Other Tribological Applications}

A project funded by the Office of Navy Research led to the successful development of MAX based materials for foil bearings, having low friction and wear from room temperature to $823 \mathrm{~K}$. Figure 9 shows a $\mathrm{Ta}_{2} \mathrm{AlC} / \mathrm{Ag}$ shaft and a superalloy foil after testing for 10000 cycles in a rig. The shaft was rotated at $50000 \mathrm{rev} \mathrm{min}^{-1}$ [329]. Honeywell Inc. was further developing this concept.
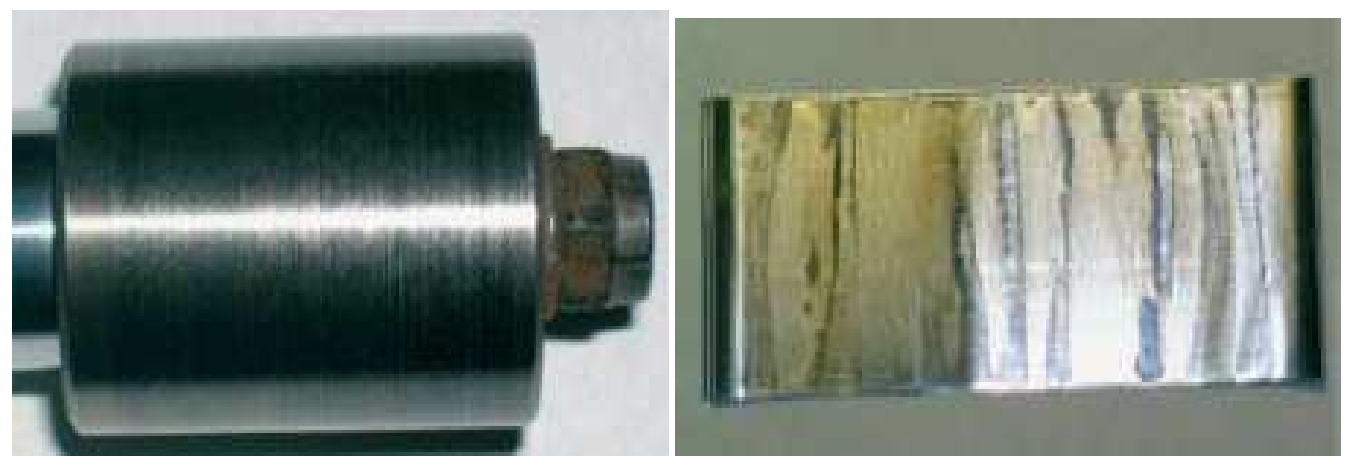

(a)(b)

Fig. 9. (a) Ta 2 AlC/Ag composite cylinder mounted on a shaft after 10000 stop-start cycles in a rig test and (b) picture of superalloy foil after rig testing [74].

\subsection{Gas Burner Nozzles}

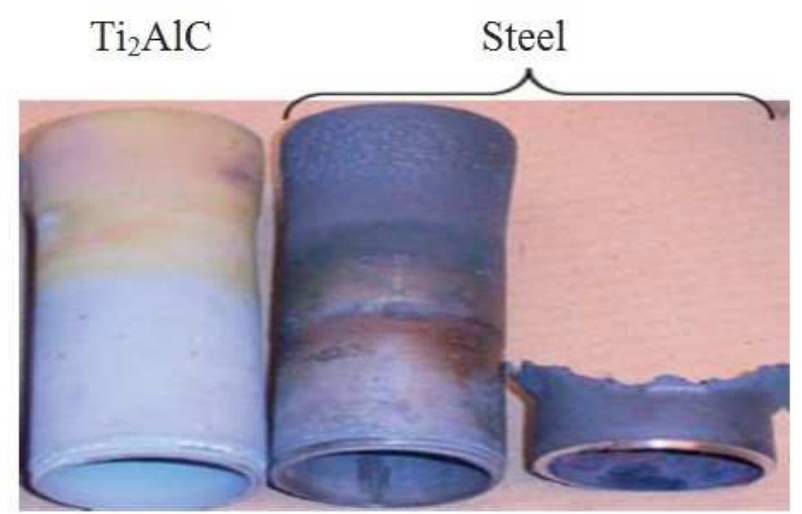

Fig. 10. Pictures of $\mathrm{Ti}_{2} \mathrm{AlC}$ and steel nozzles used in gas burners. The testing conditions that heavily corroded the steel nozzles did not appear to affect the MAX-based one.

Owing to its excellent high-temperature properties and because it forms a protective alumina layer, $\mathrm{Ti}_{2} \mathrm{AlC}$-based MAX phases can be used in gas burning applications where traditional metallic alloys show limited service life (See Fig. 10). The same MAX compound can also replace metallic alloys to increase the burner process temperatures up to 1400 ${ }^{0} \mathrm{C}$. Note that, in contrast to traditional ceramics, joining problems to existing equipment are easily overcome as MAX nozzles can be readily threaded and thus can directly replace metallic nozzles.

\subsection{Tooling for Dry Drilling of Concrete}

In the early 2000s, 3-ONE-2 (a small company Dr. T. ElRaghy) and Hilti developed tooling for the dry drilling of concrete, consisting of diamonds in MAX $312\left(\mathrm{Ti}_{3} \mathrm{SiC}_{2}\right)$ segments, which were then brazed to steel. The performance of the MAX phase segments was reported to be far superior to that of current diamond/Co segments (Fig. 11 a,b). With further improvements in design to overcome the problem of smearing of concrete powders due to high temperatures and the inadequate toughness of the segments, this material may be close to market. 

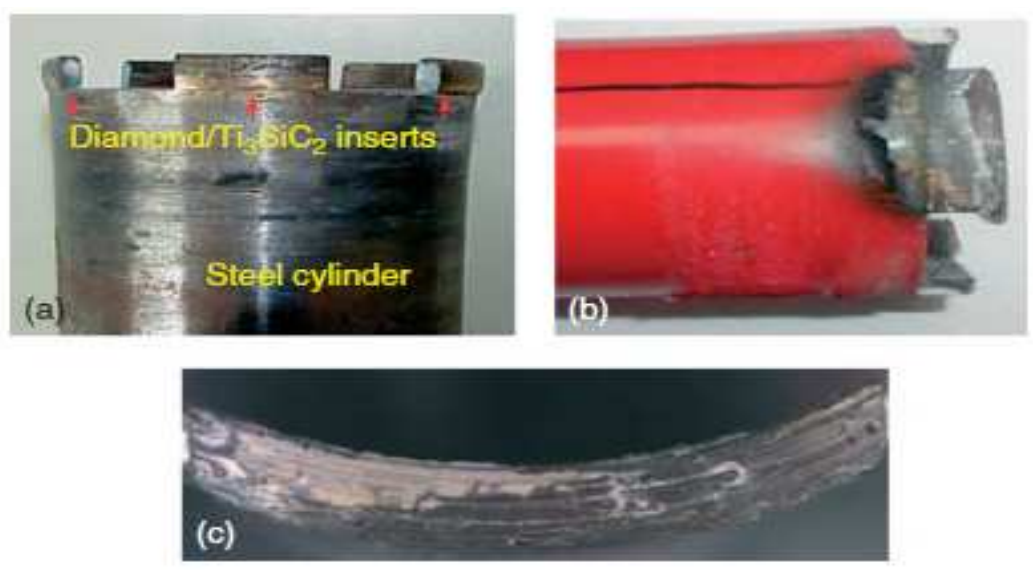

Fig. 11. Pictures of, (a) steel hollow cylinder to which diamond/Ti $i_{3} S i C_{2}$ inserts were brazed, after dry drilling of concrete, (b) same as (a), but where the diamonds were embedded in a Co matrix; and (c) higher magnification of insert after dry drilling. (Courtesy 3-ONE-2.).

\subsection{Glove and Condom Formers and Nonstick Cookware}

Ansell Healthcare and Drexel University signed a research agreement for developing gloves and condom formers to make latex products. The work resulted in the development of the slip casting technology for manufacturing large, thin- walled complex parts (see Fig. 12 a-c) and a patent. In 2007, a patent was issued (El-Raghy and Lyons, 2007) for the use of the MAX phases and their coatings as durable, stick and stain and thermal shock resistant, dishwasher safe, cookware, cutlery, and other cooking utensils.
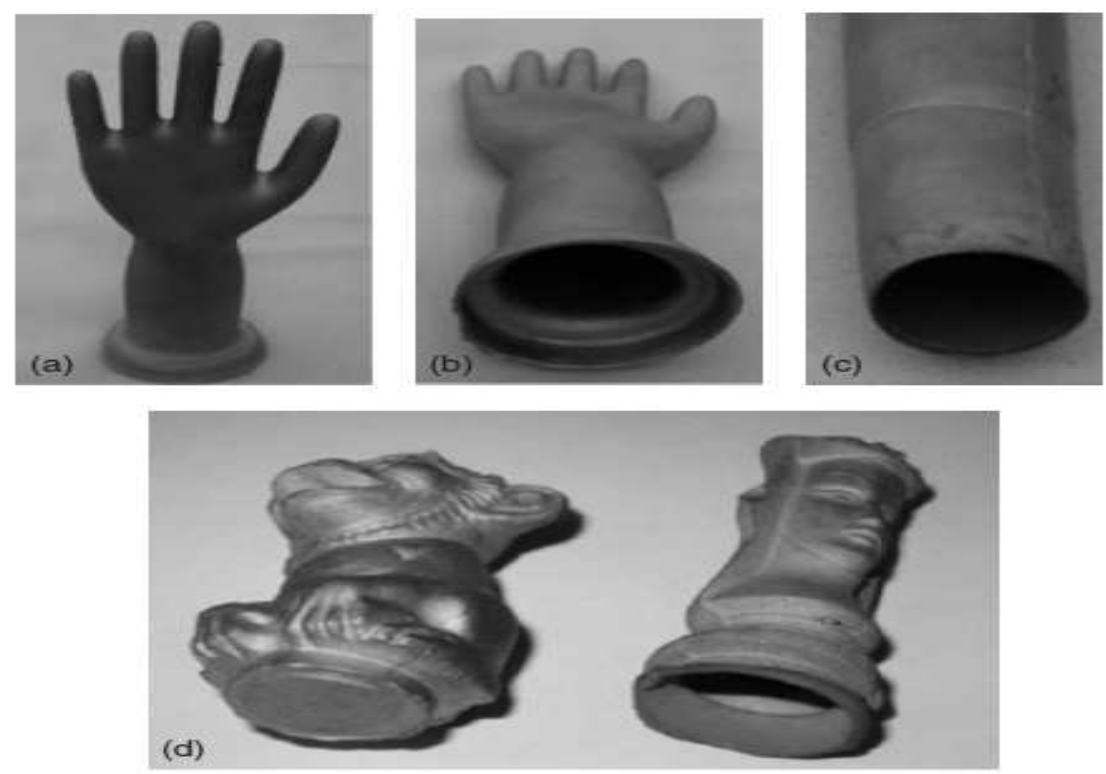

Fig. 12. Picture of (a) large, hollow, slip cast Ti ${ }_{3} S i C_{2}$ glove former; (b) and (c) same as (a), but showing thin walls possible; and (d) complex solid and hollow slip cast parts starting with Maxthal powders. (Courtesy 3-ONE-2.).

\subsection{Application in the Nuclear Industry}

There are some of the MAX phases compounds, most notably $\mathrm{Ti}_{3} \mathrm{AlC}_{2}$ and $\mathrm{Ti}_{3} \mathrm{SiC}_{2}$, are quite resistant to radiation damage (Le Flem et al., 2010; Liu et al., 2010; Napp'e et al., 2009; Whittle et al., 2010). There is also a growing body of evidence that dynamic recovery may be occurring at temperatures of $700{ }^{\circ} \mathrm{C}$ or lower. In a post-Fukushima world, it is imperative to build some accident tolerance to the Zircaloy tubes that hold the nuclear fuel. The simplest is to spray a thin coating of $\mathrm{Ti}_{2} \mathrm{AlC}$ or $\mathrm{Ti}_{3} \mathrm{AlC}_{2}$ onto the Zircaloy tubes. If the coatings are thin enough and are designed in such a way that in the presence of oxygen they form a thin cohesive and adhesive alumina layer, then it is possible to protect the Zircaloy tubes in the case of accident due to loss of coolant. The challenge, however, is to thermally spray the $\mathrm{Ti}_{2} \mathrm{AlC}$ such that it does not lose its ability to form thin alumina layers. The current text on the topic shows that after high-velocity oxy-fuel, $\mathrm{HVOF}$, spraying of $\mathrm{Ti}_{2} \mathrm{AlC}$, heating in air results in the formation of titania instead of alumina (Frodelius et al., 2008; Sonestedt et al., 2010a,b). The fact 
that $\mathrm{Ti}_{3} \mathrm{SiC}_{2}$ does not react with molten $\mathrm{Pb}$ and or $\mathrm{Pb}-\mathrm{Bi}$ alloys (Barnes, Dietz Rago, and Leibowitz, 2008; Heinzel, M“uller, and Weisenburger, 2009; Utili et al., 2011) renders it a good material to be used for containing molten $\mathrm{Pb}$ or $\mathrm{Pb}-\mathrm{Bi}$ alloys in nuclear reactors. In a recent paper, Sienicki et al. (2011) suggested that $\mathrm{Ti}_{3} \mathrm{SiC}_{2}$ could be used in an improved natural circulation $\mathrm{Pb}$-cooled small modular fast reactor.

\subsection{Ignition Devices and Electrical Contacts}

Some of the MAX phases are used as the conductive element in spark plugs and other such ignition devices (Walker, 2010).One of the first applications for $\mathrm{Ti}_{3} \mathrm{SiC}_{2}$ was by a small Swedish company, Impact Coatings, as sputtering targets for the deposition of electrical contacts. Although the company now uses other cheaper targets, this early application is significant. Currently, others are sputter depositing $\mathrm{Cr}_{2} \mathrm{AlC}$ thin films on steels and turbineblades (e.g. Hajas et al., 2011). In some cases, MAX phase targets are used. On the basis of the growing worldwide interest in the MAX phases, it is reasonable to assume that a market for sputter targets should emerge soon. Owing to their good electrical conductivity and tribological properties, in addition to the acceptable mechanical properties, MAX phases such as $\mathrm{Ti}_{3} \mathrm{SiC}_{2}$ and $\mathrm{Ti}_{3} \mathrm{AlC}_{2}$ have been shown to perform better than carbon based pantographs for electric trains. Currently, a few leading projects are running in China, aiming for application on the high speed railway under construction.

\subsection{Electrical Contact for SiC-based Devices}

Presently, SiC-based devices are under development for use in electronic devicesthat are subjected to high temperatures and/or corrosive environments. Siliconcarbide's material properties (large band-gap, high-thermal conductivity, extremely high-melting and decomposition temperatures, excellent mechanical properties, and exceptional chemical stability) are far superior to those of $\mathrm{Si}$ and render it suitable for operation in hostile environments. Because its band gap is nearly three times larger than that of $\mathrm{Si}$, it is possible to use $\mathrm{SiC}$ as a semiconductor, for example, to temperatures as high as $1000{ }^{0} \mathrm{C}$ because of its low intrinsic carrier concentrations and operation within the dopant-controlled saturation regime required for semiconducting devices. One of the challenges of this technology isto find a material to use as an electrical contact that does not react with $\mathrm{SiC}$ at elevated temperatures and results in low contact resistances. In 2003, a patent was issued (Tuller, Spears, and Mlcak, 2003) for the use of $\mathrm{Ti}_{3} \mathrm{SiC}_{2}$ as an electrical contact for $\mathrm{SiC}$ electronic components. The major advantage of $\mathrm{Ti}_{3} \mathrm{SiC}_{2}$ is that it is in thermodynamic equilibrium with $\mathrm{SiC}$. This would in turn allow the $\mathrm{SiC}$ devices to be operated in high-temperature environments without the contact material reacting with the $\mathrm{SiC}$, and deteriorating the performance of the device. Some sensor applications are based on $\mathrm{SiC}$ field effect transistors that exploit the wide band gap of $\mathrm{SiC}$ and its chemical inertness. In such applications, there is also need a compatible inert electrode material such as $\mathrm{Ti}_{3} \mathrm{SiC}_{2}$.

\subsection{Forming Processes and Sintering}

One of the crucial advantages of working with the MAX phases is that they can be pressureless sintered to full density by heating green performs in inert atmospheres such as argon The first report in the open literature for the pressureless sintering of a MAX phase to full density can be found in a patent that issued in 2002 (El-Raghy et al., 2002). The first paper published in 2004 (Murugaiah et al., 2004) not only on the pressureless sintering of $\mathrm{Ti}_{3} \mathrm{SiC}_{2}$ but also on its tape casting, a process that, not surprisingly, led to orienting the flaky prereacted hexagonal grains. In this paper, it was shown that the simplest method to producing highly oriented microstructures was to gently shake or tap the dies containing the prereacted Kanthal powders prior to sintering. The first paper published on the pressureless sintering in 2006 (Zhou et al., 2006). In general, the fact that the MAX phases can be sintered to full density, without the application of pressure is an important attribute that greatly enhances their chances for commercialization. The methods for forming the green bodies are quite varied. They range from slip casting, to produce complex, thin wall shapes (e.g., Figure 11), extrusion to form tubes (Figure 9), cold pressing to form simple shapes (Figure 7) and cold isostatic pressing to metal injection molding. It is significance noting that the inherent ductility of the MAX phases help to forming green bodies without help of any binder. Spark plasma sintering (SPS) is also emerging as a viable method to fabricate and densify the MAX phases (Cui et al., 2012; Hu et al., 2009, 2011b; Zhang et al., 2003). Currently there is little work, however, comparing the high-temperature properties of samples made by SPS with those made by reactive hot pressing or pressureless sintered commercial powders.

In addition to the applications mentioned above, a number of other potential applications have been found. These include: electrodes, exhaust gas filters for automobiles, freecutting elements, microelectronics, biomaterials, damping materials (high stiffness and up to high temperatures), corrosion resistant materials, surface coatings, defense applications, such as armor, nuclear applications, low dimensional materials, and substrates for CVD diamond.

\section{Conclusion}

The MAX phases have attracted considerable attention and are garnering new devotees because they have a quite unusual combination of properties. The fact that their chemistries can be altered while keeping the structure the same allows for relatively rapid understanding. The emergence of possibly magnetic MAX phases is an exciting development that would greatly enhance their potential applications. On the mechanical side, the fact that dislocations are confined to $2 \mathrm{D}$ is proving invaluable in elucidating the deformation behavior of layered solids in general, and ones that are also conductive in particular. The most urgent issue in MAX phase research is to develop 
viable commercial applications for these materials. With the preliminary and potential application fields discussed above, market penetration by MAX phase materials will create more stimuli to carry out more research and development on this family of layered metallic ceramics. Research on MAX phases is currently funded by agencies, science foundations and defense industries in the USA, China, Europe and Australia. However, funding for research on MAX phases from governmental agencies in Japan is almost zero. The likelihood of the Japanese government funding such research remains small until a clear market scenario is available.

Another important issue is the search for new MAX phases. First, to better understand the MAX phases themselves, both those known to exist and those theoretically predicted to be thermodynamically and mechanically stable. To do so, thorough experimental investigations into the properties are needed. The second priority is to discover more MAX phases. It is encouraging that in the past few years many MAX phases, particularly 413 and 312 phases, have been discovered. More 312 or 211 MAX phases, plus their solid solutions, which are numerous, are awaiting exploration. In this review paper we have studied most of the MAX phase compounds, their different properties and applications in different sectors. We hope that the researches described in this overview will be helpful for the discovery of new MAX phase compound and their practical and possible applications in modern technology in near future.

\section{References}

[1] M. W. Barsoum: Prog. Solid State Chem., 2000, 28, 201-281.

[2] Z. M. Sun, H. Hashimoto, Z. F. Zhang, S. L. Yang and S. Tada: Mater. Trans., 2006, 47, 170-174.

[3] W. Jeitschko, H. Nowotny, and F. Benesovsy, Monatsh. Chem., 94, 672 (1963).

[4] W. Jeitschko, H. Nowotny, and F. Benesovsy, Monatsh. Chem., 94, 844 (1963).

[5] W. Jeitschko, H. Nowotny, and F. Benesovsy, Monatsh. Chem., 94, 1198 (1964).

[6] W. Jeitschko, H. Nowotny, and F. Benesovsy, Monatsh. Chem., 95, 178 (1964).

[7] W. Jeitschko, H. Nowotny, and F. Benesovsy, Monatsh. Chem., 95, 1004 (1964).

[8] M. W. Barsoum, Prog. Solid State Chem., 28, 201 (2000).

[9] H. B. Zhang, Y. W. Bao, and Y. C. Zhou, J. Mater Sci. Technol., 25, 1 (2009).

[10] J. Y. Wang and Y. C. Zhou, Annual Rev. Mater. Res., 39, 415 (2009).

[11] P. Eklund, M. Beckers, U. Jansson, et al., Thin Solid Films, 518, 1851 (2010).

[12] J. P. Palmquist, S. Li, P. O. Persson, et al., Phys. Rev., B70, 165401 (2004).
[13] H. Hogberg, P. Eklund, J. Emmerlich, et al., J. Mater. Res., 20, 779 (2005).

[14] S. E. Lofland, J. D. Hettinger, T. Meehan, et al., Phys. Rev., B74, 174501 (2006).

[15] A. D. Bortolozo, Z. Fisk, O. H. Sant'Anna, et al., Physica, C469, 256 (2009).

[16] Barsoum, M.W., Brodkin, D., \& El-Raghy, T., Layered Machinable Ceramics, For High Temperature Applications. Scrip. Met. et. Mater. 36, 535-541 (1997)

[17] Nowotny, H., Struktuchemie Einiger Verbindungen der Ubergangsmetalle mit den elementen $\mathrm{C}, \mathrm{Si}, \mathrm{Ge}, \mathrm{Sn}$. Prog. Solid State Chem. 2, 27 (1970)

[18] Barsoum, M.W. \& El-Raghy, T., Synthesis and Characterization of a Remarkable Ceramic: $\mathrm{Ti}_{3} \mathrm{SiC}_{2}$. J. Amer. Cer. Soc. 79 (7), 1953-1956 (1996)

[19] Barsoum, M.W. \& El-Raghy, T., Synthesis and Characterization of a Remarkable Ceramic: $\mathrm{Ti}_{3} \mathrm{SiC}_{2}$. J. Amer. Cer. Soc. 79 (7), 1953-1956 (1996)

[20] Yuxiang Mo, Paul Rulis, and W.Y. Ching, Yuxiang Mo, Paul Rulis, W.Y. Ching, Electronic structure and Optical properties of 20 MAX phase compounds, submitted to Phys. Rev. B. (2012).

[21] T. H. Scabarozi, J. Roche, A. Rosenfeld, S. H. Lim, L. Salamanca-Riba, I. Takeuchi, M. W.Barsoum, J. D. Hettinger, S. E. Lofland, Synthesis and Characterization of Nb2AlC Thin Films, Thin Solid Films, 517, 2920-2933 (2009).

[22] C. M. Fang, R. Ahuja and O. Eriksson: J. Appl. Phys., 2007, $101,013511$.

[23] G. Hug: Phys. Rev. B, 2006, 74B, 184113.

[24] D. Music, Z. M. Sun and J. M. Schneider: Solid State Commun., 2005, 133, 381-383.

[25] S. Dubois, T. Cabioc'h, P. Chartier, V. Gauthier and M. Jaouen: J. Am. Ceram. Soc., 2007, 90, 2642- 2644.

[26] M. B. Kanoun and M. Jaouen: J. Phys.-Cond. Matter, 2008, 20, 085211 .

[27] J. Etzkorn, M. Ade and H. Hillebrecht: Inorg. Chem., 2007, 46, $1410-1418$

[28] Y. C. Zhou, F. L. Meng and J. Zhang: J. Am. Ceram. Soc., 2008, 91, 1357-1360.

[29] A. Grechnev, S. Li, R. Ahuja, O. Eriksson, U. Jansson and O. Wilhelmsson: Appl. Phys. Lett., 2004, 85, 3071-3073.

[30] H. Ho"gberg, P. Eklund, J. Emmerlich, J. Birch and L. Hultman: J. Mater. Res., 2005, 20, 779-782.

[31] C. F. Hu, Z. J. Lin, L. F. He, Y.W. Bao, J. Y. Wang,M. S. Li and Y. C. Zhou: J. Am. Ceram. Soc., 2007, 90, 2542-2548.

[32] C. F. Hu, F. Z. Li, L. F. He, M. Y. Liu, J. Zhang, J. M. Wang, Y. W. Bao, J. Y. Wang and Y. C. Zhou: J. Am. Ceram. Soc., 2008, 91, 2258-2263.

[33] M. W. Barsoum, J. Golczewski, H. J. Seifert and F. Aldinger: J. Alloys Compd, 2002, 340, 173-179.

[34] T. El-Raghy, S. Chakraborty and M. W. Barsoum: J. Eur. Ceram. Soc., 2000, 20, 2619-2625. 
[35] W. B. Tian, P. L. Wang, G. J. Zhang, Y. M. Kan, Y. X. Li and D. S. Yan: Scr. Mater., 2006, 54, 841846.

[36] Holm, B., Ahuja, R., Li, S., and Johansson,B. (2002) Theory of ternary layered systemTi-Al-N. J. Appl. Phys., 91, 98749877.

[37] Li, C.-W. and Wang, Z. (2010) Firstprinciplesstudy of structural, electronic,and mechanical properties of the nanolaminatecompound $\mathrm{Ti}_{4} \mathrm{GeC}_{3}$ under pressure.J. Appl. Phys., $107,123511$.

[38] Du, Y.L., Sun, Z.M., Hashimoto, H., andTian, W.B. (2008a) Elastic propertiesof $\mathrm{Ta}_{4} \mathrm{AlC}_{3}$ studied by firstprinciplescalculations. Solid State Commun., 147,246-249.

[39] Wang, J., Zhou, Y., Lin, Z., and Hu, J. (2008)Ab initio study of polymorphism in layeredternary carbide $\mathrm{M}_{4} \mathrm{AlC}_{3}(\mathrm{M}=\mathrm{V}$, Nband Ta). Scr. Mater., 58, 1043-1046.

[40] He, X., Bai, Y., Zhu, C., and Barsoum, M.W.(2011) Polymorphism of newly-discovered $\mathrm{Ti}_{4} \mathrm{GaC}_{3}$ : a first-principle study. ActaMater., 59, 5523-5533.

[41] He, X., Bai, Y., Zhu, C., Sun, Y., Li, M., andBarsoum, M.W. (2010) General trendsin the structural, electronic and elasticproperties of the $\mathrm{M}_{3} \mathrm{AlC}_{2}$ phases $(\mathrm{M}=$ transition metal): a first-principle study.Comput. Mater. Sci., 49, 691-698.

[42] Holm, B., Ahuja, R., and Johansson, B.(2001) Ab initio calculations of the mechanicalproperties of $\mathrm{Ti}_{3} \mathrm{SiC}_{2}$. Appl. Phys.Lett., 79, 1450.

[43] Finkel, P., Seaman, B., Harrell, K.,Hettinger, J.D., Lofland, S.E., Ganguly,A., Barsoum, M.W., Sun, Z., Li, S., andAhuja, R. (2004) Low temperature elastic,electronic and transport properties of $\mathrm{Ti}_{3} \mathrm{Si}_{1-\mathrm{x}} \mathrm{GexC}_{2}$ solid solutions. Phys. Rev. B,70, 085104.

[44] Sun, Z., Li, S., Ahuja, R., and Schneider,J.M. (2004) Calculated elastic properties of $\mathrm{M}_{2} \mathrm{AlC}(\mathrm{M}=\mathrm{Ti}, \mathrm{V}, \mathrm{Cr}, \mathrm{Nb}$ and Ta). SolidState Commun., 129, 589-592.

[45] Du, Y.L., Sun, Z.-M., Hashimoto, H., andBarsoum, M.W. (2009a) Theoreticalinvestigations on the elastic and thermodynamicproperties of $\mathrm{Ti}_{2} \mathrm{AlC}_{0.5} \mathrm{~N}_{0.5}$ solid solution. Phys. Lett. A, 374, 78-82.

[46] Du, Y.L., Sun, Z.M., Hashimoto, H., andTiana, W.B. (2008b) First-principlesstudy on electronic structure and elasticproperties of $\mathrm{Ti}_{2} \mathrm{SC}$. Phys. Lett. A, 372,5220-5223.

[47] Bouhemadou, A. (2009a) Calculated structural,electronic and elastic properties ofM2 $\mathrm{GeC}(\mathrm{M}=\mathrm{Ti}, \mathrm{V}, \mathrm{Cr}, \mathrm{Zr}, \mathrm{Nb}, \mathrm{Mo}, \mathrm{Hf}, \mathrm{Ta}$ and W). Appl. Phys. A, 96, 959-967.

[48] Bouhemadou, A. (2008b) Prediction studyof structural and elastic properties underpressure effect of $\mathrm{M}_{2} \mathrm{SnC}(\mathrm{M}=\mathrm{Ti}, \mathrm{Zr}$, Nb,Hf). Physica B-Condens. Matter, 403, 2707.

[49] Bouhemadou, A. and Khenata, R. (2007)Prediction study of structural and elasticproperties under the pressure effect ofM $_{2} \mathrm{GaC}, \mathrm{M}=\mathrm{Ti}$, V, Nb, Ta. J. Appl. Phys., 102, 043528.

[50] Bouhemadou, A. and Khenata, R. (2008)Structural, electronic and elastic propertiesof $\mathrm{M}_{2} \mathrm{SC}(\mathrm{M}=\mathrm{Ti}, \mathrm{Zr}, \mathrm{Hf})$ compounds.Phys. Lett. A, 372, 6448-6452.

[51] Wang, J. and Zhou, Y. (2004a) Dependenceof elastic stiffness on electronic bandstructure of nanolaminate $\mathrm{M}_{2} \mathrm{AlC}(\mathrm{M}$ $=\mathrm{Ti}, \mathrm{V}, \mathrm{Nb}$ and $\mathrm{Cr}$ ) ceramics. Phys. Rev. B,69, 214111.
[52] Sun, Z., Li, S., Ahuja, R., and Schneider,J.M. (2004) Calculated elastic properties of $\mathrm{M}_{2} \mathrm{AlC}(\mathrm{M}=\mathrm{Ti}, \mathrm{V}, \mathrm{Cr}, \mathrm{Nb}$ and Ta). SolidState Commun., 129, 589-592.

[53] Bai, Y., He, X., Li, M., Sun, Y., Zhu, C., andLi, Y. (2010) Ab initio study of the bondingand elastic properties of $\mathrm{Ti}_{2} \mathrm{CdC}$. SolidState Sci., 12, 144-147.

[54] Cover, M.F., Warschkow, O., Bilek, M.M.,and McKenzie, D.R. (2009) A comprehensivesurvey of $\mathrm{M}_{2} \mathrm{AX}$ phase elasticproperties. J. Phys.: Condens. Matter, 21,305403.

[55] Kanoun, M.B., Goumri-Said, S., and Reshak,A.H. (2009b) Theoretical study of mechanical,electronic, chemical bondingand optical properties of Ti2 $\mathrm{SnC}, \mathrm{Zr}_{2} \mathrm{SnC}, \mathrm{Hf}_{2} \mathrm{SnC}$ and $\mathrm{Nb}_{2}$ SnC. Comput. Mater. Sci.,47, 491-500.

[56] Kanoun, M.B., Goumri-Said, S., and Jaouen, M. (2009a) Steric effect on the $\mathrm{M}$ site of nanolaminate compounds $\mathrm{M}_{2} \mathrm{SnC}$ $(\mathrm{M}=\mathrm{Ti}, \mathrm{Zr}$, Hf and $\mathrm{Nb})$. J. Phys.: Condens.Matter, 21, 045404-045406.

[57] Scabarozi, T.H., Amini, S., Leaffer, O., Ganguly, A., Gupta, S., Tambussi, W., Clipper, S., Spanier, J.E., Barsoum, M.W., Hettinger, J.D. et al. (2009) Thermal expansion of select MAX phases measured by high temperature X-ray diffraction and dilatometry. J. Appl. Phys, 105, 013543.

[58] P. Hohenberg and W. Kohn, Phys. Rev. 136, B864 (1964).

[59] W. Kohn and L. J. Sham, Phys. Rev. A 140, 1133 (1965).

[60] W. Y. Ching and P. Rulis, Phys. Rev. B 73, 045202 (2006).

[61] W. Y. Ching, L. Ouyang, P. Rulis, and H. Yao, Phys. Rev. B 78, 014106 (2008).

[62] W. Y. Ching and P. Rulis, Phys. Rev. B 77, 035125 (2008).

[63] L. Liang, P. Rulis, B. Kahr, and W. Y. Ching, Phys. Rev. B 80, $235132(2009)$

[64] S. Aryal, P. Rulis, and W. Y. Ching, Am. Mineral. 93, 114 (2008).

[65] L. Liang, P. Rulis, and W. Y. Ching, Acta Biomater. 6, 3763 (2010).

[66] W. Y. Ching, S. Aryal, P. Rulis, and W. Schnick, Phys. Rev. B 83, 155109 (2011).

[67] P. Rulis and W. Ching, J. Mater. Sci. 46, 4191 (2011).

[68] P. Rulis, H. Yao, L. Ouyang, and W. Y. Ching, Phys. Rev. B 76, 245410 (2007).

[69] W. Y. Ching, P. Rulis, L. Ouyang, and A. Misra, Appl. Phys. Lett. 94, 051907 (2009).

[70] W. Y. Ching, P. Rulis, L. Ouyang, S. Aryal, and A. Misra, Phys. Rev. B 81, 214120 (2010)

[71] L. Liang, P. Rulis, L. Ouyang, and W. Y. Ching, Phys. Rev. B 83, 024201 (2011).

[72] M. Born and K. Huang, Dynamical Theory of Crystal Lattices (Clarendon, Oxford, 1956).

[73] E. I. Isaev, S. I. Simak, I. A. Abrikosov, R. Ahuja, Y. K. Vekilov, M. I. Katsnelson, A. I. Lichtenstein, and B. Johansson, J. Appl. Phys. 101, 123519 (2007). 
[74] S. Gupta, D. Filimonov, T. Palanisamy, T. El-Raghy and M. W. [75] K. Tanaka, M. Koiwa, Intermetallics 4 (1996) S29eS39. Barsoum: Wear, 2007, 262, 1479-1489.

[76] S.F. Pugh, Philos. Mag. 45 (1954) 823. 